Atmos. Chem. Phys., 19, 14621-14636, 2019

https://doi.org/10.5194/acp-19-14621-2019

(C) Author(s) 2019. This work is distributed under

the Creative Commons Attribution 4.0 License.

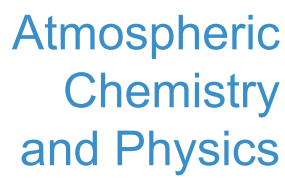

(c) (P)

\title{
Impact of convectively lofted ice on the seasonal cycle of water vapor in the tropical tropopause layer
}

\author{
Xun Wang ${ }^{1}$, Andrew E. Dessler ${ }^{1}$, Mark R. Schoeberl ${ }^{2}$, Wandi Yu ${ }^{1}$, and Tao Wang ${ }^{3, a}$ \\ ${ }^{1}$ Department of Atmospheric Sciences, Texas A\&M University, College Station, TX, USA \\ ${ }^{2}$ Science and Technology Corporation, Columbia, MD, USA \\ ${ }^{3}$ Earth System Science Interdisciplinary Center, University of Maryland, College Park, MD \\ anow at: NASA Jet Propulsion Laboratory, California Institute of Technology, Pasadena, CA
}

Correspondence: Andrew E. Dessler (adessler@tamu.edu)

Received: 29 March 2019 - Discussion started: 29 April 2019

Revised: 2 October 2019 - Accepted: 23 October 2019 - Published: 3 December 2019

\begin{abstract}
We use a forward Lagrangian trajectory model to diagnose mechanisms that produce the water vapor seasonal cycle observed by the Microwave Limb Sounder (MLS) and reproduced by the Goddard Earth Observing System Chemistry-Climate Model (GEOSCCM) in the tropical tropopause layer (TTL). We confirm in both the MLS and GEOSCCM that the seasonal cycle of water vapor entering the stratosphere is primarily determined by the seasonal cycle of TTL temperatures. However, we find that the seasonal cycle of temperature predicts a smaller seasonal cycle of TTL water vapor between 10 and $40^{\circ} \mathrm{N}$ than observed by MLS or simulated by the GEOSCCM. Our analysis of the GEOSCCM shows that including evaporation of convective ice in the trajectory model increases both the simulated maximum value of the $100 \mathrm{hPa} 10-40^{\circ} \mathrm{N}$ water vapor seasonal cycle and the seasonal-cycle amplitude. We conclude that the moistening effect from convective ice evaporation in the TTL plays a key role in regulating and maintaining the seasonal cycle of water vapor in the TTL. Most of the convective moistening in the $10-40^{\circ} \mathrm{N}$ range comes from convective ice evaporation occurring at the same latitudes. A small contribution to the moistening comes from convective ice evaporation occurring between $10^{\circ} \mathrm{S}$ and $10^{\circ} \mathrm{N}$. Within the 10 $40^{\circ} \mathrm{N}$ band, the Asian monsoon region is the most important region for convective moistening by ice evaporation during boreal summer and autumn.
\end{abstract}

\section{Introduction}

Stratospheric water vapor is important for the radiative budget of the atmosphere and the regulation of stratospheric ozone (e.g., Solomon et al., 1986; Dvortsov and Solomon, 2001). One of the key features of the tropical lower stratospheric (LS) water vapor is its seasonal cycle, often referred to as the "tape recorder" (Mote et al., 1995, 1996). The amount of water vapor entering the stratosphere and its seasonal cycle is primarily controlled by temperatures in the tropical tropopause layer (TTL) (Brewer, 1949; Holton et al., 1995; Fueglistaler et al., 2009). The low TTL temperatures freeze-dry the air, reducing the water vapor mixing ratios and imprinting the seasonal cycle on air ascending into the stratosphere through the TTL (e.g., Mote et al., 1996; Fueglistaler, 2005; Schoeberl et al., 2008; Fueglistaler et al., 2009).

Analyses of observations have suggested that deep convection reaching the TTL may also be important for regulating the amount of water vapor entering the stratosphere. Nielsen et al. (2007) and Corti et al. (2008) suggested that deep-penetrating convection deposits ice particles above the cold point tropopause, where ice may evaporate and cause a moistening effect. This idea is also supported by observations of enrichment of the deuterated isotopologue of water vapor (HDO) in the tropical LS (Moyer et al., 1996; Dessler et al., 2007; Steinwagner et al., 2010). The role of convective ice evaporation in the stratospheric entry water vapor has also been addressed in several model studies. Schoeberl et al. $(2014,2018,2019)$ quantified the global impact of convective ice on winter 2008/2009 water vapor between 18 and $30 \mathrm{~km}$ and concluded that, for global average water vapor be- 
tween 18 and $30 \mathrm{~km}$ during winter, the convective ice evaporation plays a small role, since convection rarely reaches the level of the tropopause cold point. During El Niño events, convective ice evaporation appears to play a larger role in the interannual variability of TTL and LS water vapor (Avery et al., 2017; Ye et al., 2018). On longer timescales, convective ice evaporation was found to contribute to an important fraction of the increase in stratospheric entry water vapor over the next century in two chemistry-climate models (Dessler et al., 2016).

The goal of this paper is to investigate the impact of convective moistening on the seasonal cycle of water vapor entering the stratosphere. Previous analyses have separately investigated the winter/summer impact, interannual variability, and the long-term trend (Ueyama et al., 2015, 2018; Dessler et al., 2016; Avery et al., 2017; Schoeberl et al., 2014, 2018; Ye et al., 2018). However, less work has been done on understanding the impact of convective ice on the seasonal cycle. The basics of the water vapor seasonal cycle can be understood simply: more water vapor enters the LS during boreal summer, when TTL temperatures are generally higher and vice versa during boreal winter. Observations (Fig. 1a-c) reveal that zonal mean water vapor is observed to have a larger amplitude seasonal cycle in the NH subtropics near the tropopause level (e.g., Rosenlof, 1997; Randel et al., 1998, 2001, and references therein), despite the fact that the temperature seasonal cycle is symmetric about the Equator (Fig. 1b-c). We will refer to this as "the hemispheric asymmetry". At higher altitudes, the hemispheric asymmetry gradually disappears (Fig. 1a) (e.g., Randel et al., 1998, 2001).

Previous studies have suggested that this hemispheric asymmetry structure in the water vapor seasonal cycle is due to processes within the Southeast Asian monsoon and North American monsoon region, including both diabatic and adiabatic transport in the TTL (Rosenlof, 1997; Randel et al., 1998; Dethof et al., 1999; Bannister et al., 2004; Gettelman et al., 2004; Pan et al., 1997, 2000, Park et al., 2004, 2007; Wright et al., 2011; Ploeger et al., 2013). Indeed, the Microwave Limb Sounder (MLS) data (Fig. 2c) show that the summertime maxima of the $100 \mathrm{hPa}$ water vapor are confined in the Asian monsoon and North American monsoon anticyclones (Rosenlof, 1997; Jackson et al., 1998; Randel et al., 1998, 2001; Dessler and Sherwood, 2004; Randel and Park, 2006; Park et al., 2007; Bian et al., 2012) and become weaker above $100 \mathrm{hPa}$ (Fig. 2a-b).

Many previous studies have investigated the impact of convection within the monsoon regions on the budget of the stratospheric entry water vapor. Dessler and Sherwood (2004) used a budget model with and without convection and concluded that, during summer, moistening by deep-penetrating convection increases the Northern Hemisphere (NH) extratropical water vapor at the $380 \mathrm{~K}$ isentrope by $40 \%$. Fu et al. (2006) suggested that the deep convection over the Tibetan Plateau acts as a short circuit of water vapor ascending across the tropical tropopause. James et al. (2008) used a trajectory model and concluded that air parcels are lifted by convection over Southeast Asia and then transported into the TTL by the monsoon anticyclone, avoiding the cold pool in the deep tropics. However, they pointed out that direct convective injection has a limited impact on the $100 \mathrm{hPa}$ water vapor budget, contributing to $0.3 \mathrm{ppmv}$ of the water vapor in the Asian monsoon region. Schwartz et al. (2013) provided evidence of occasional enhanced 100 and $82.5 \mathrm{hPa}$ water vapor by convective injection over the Asian and North American monsoon regions using satellite observations. Randel et al. (2015) investigated subseasonal variations in $100 \mathrm{hPa}$ water vapor in $\mathrm{NH}$ monsoon regions and suggested that stronger convection leads to lower TTL temperatures in the monsoon regions, which results in less LS water vapor there, thereby concluding that the LS water vapor in the monsoon regions is mainly controlled by large-scale transport and TTL temperatures there. Ueyama et al. (2018) investigated the convective moistening effect on $100 \mathrm{hPa}$ water vapor during boreal summer. They used a trajectory model that includes cloud formation, gravity waves, and convective moistening and concluded that convection moistens the water vapor averaged over $10^{\circ} \mathrm{S}-50^{\circ} \mathrm{N}$ by $0.6 \mathrm{ppmv}(\sim 15 \%)$ and that convective moistening over the Asian monsoon region plays an important role.

The role of convective ice evaporation in the TTL during boreal summer is still under debate. Furthermore, its impact on the TTL water vapor seasonal cycle has not been fully explored. In this study, we quantitatively investigate the impact of convective ice evaporation on the seasonal cycle of water vapor in the TTL.

\section{Models and data}

\subsection{MLS water vapor}

We analyze here version 4.2 level 2 water vapor retrieved from the Earth Observing System (EOS) Microwave Limb Sounder (MLS) instrument on the Aura spacecraft (Livesey et al., 2017). Since August 2004, the MLS provides 3500 vertical scans of the earth's limb from the surface to $90 \mathrm{~km}$ each day, covering a latitude range of $82^{\circ} \mathrm{S}$ to $82^{\circ} \mathrm{N}$ with a horizontal resolution of $1.5^{\circ}$ along the orbit track (Lambert et al., 2007). The MLS water vapor retrieval has a vertical resolution of about $3 \mathrm{~km}$ in the TTL, with a precision at 100 and $82.5 \mathrm{hPa}$ of $15 \%$ and $7 \%$, respectively. The accuracy of the water vapor at 100 and $82.5 \mathrm{hPa}$ is $8 \%$ and $9 \%$, respectively (Livesey et al., 2017). We composite the daily standard water vapor between August 2004 to October 2018 to produce monthly means on a horizontal grid of $4^{\circ}$ latitude by $8^{\circ}$ longitude following the data screening in Livesey et al. (2017). 

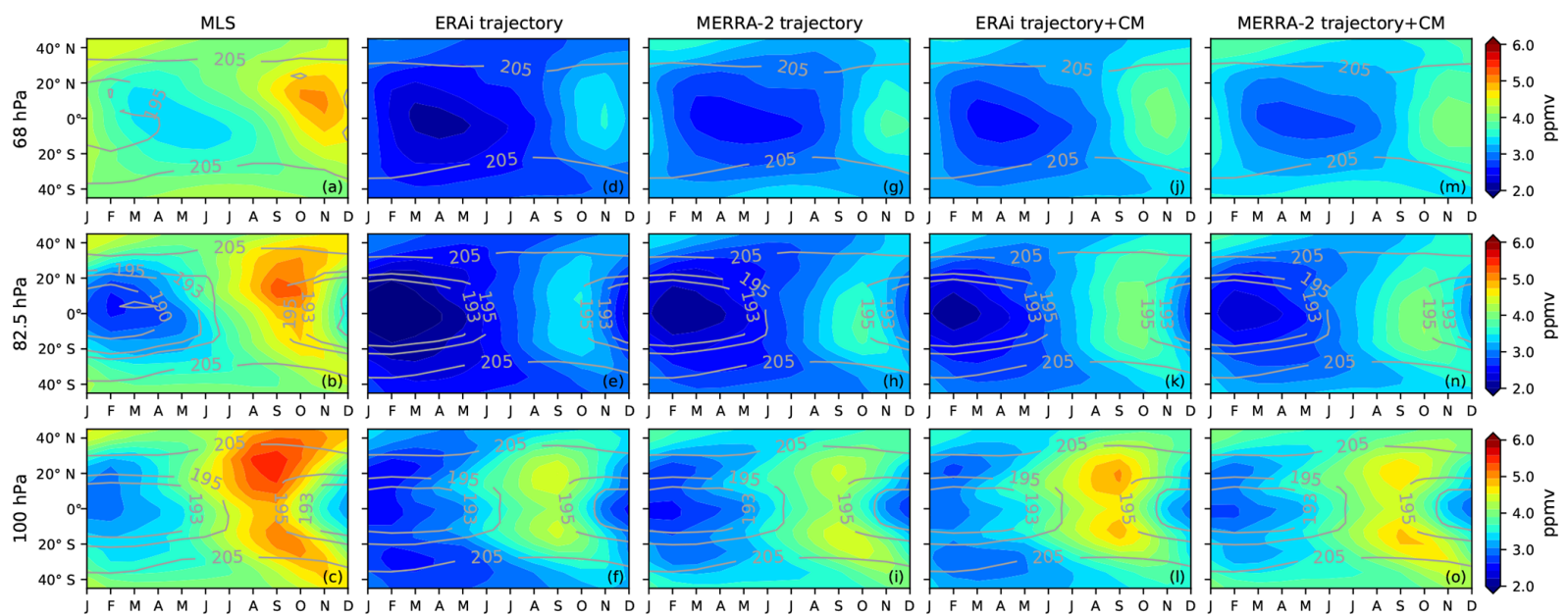

Figure 1. Zonal mean seasonal cycle of water vapor (ppmv, color shading) and temperature (K, contour lines) between $40^{\circ} \mathrm{S}$ and $40^{\circ} \mathrm{N}$ from the (a-c) MLS; (d-f) ERA-Interim (ERAi) trajectory model; (g-i) MERRA-2 trajectory model; (j-l) ERAi trajectory model with the cloud model; and (m-o) MERRA-2 trajectory model with the cloud model at $68 \mathrm{hPa}$ (top row), $82.5 \mathrm{hPa}$ (middle row), and $100 \mathrm{hPa}$ (bottom row).
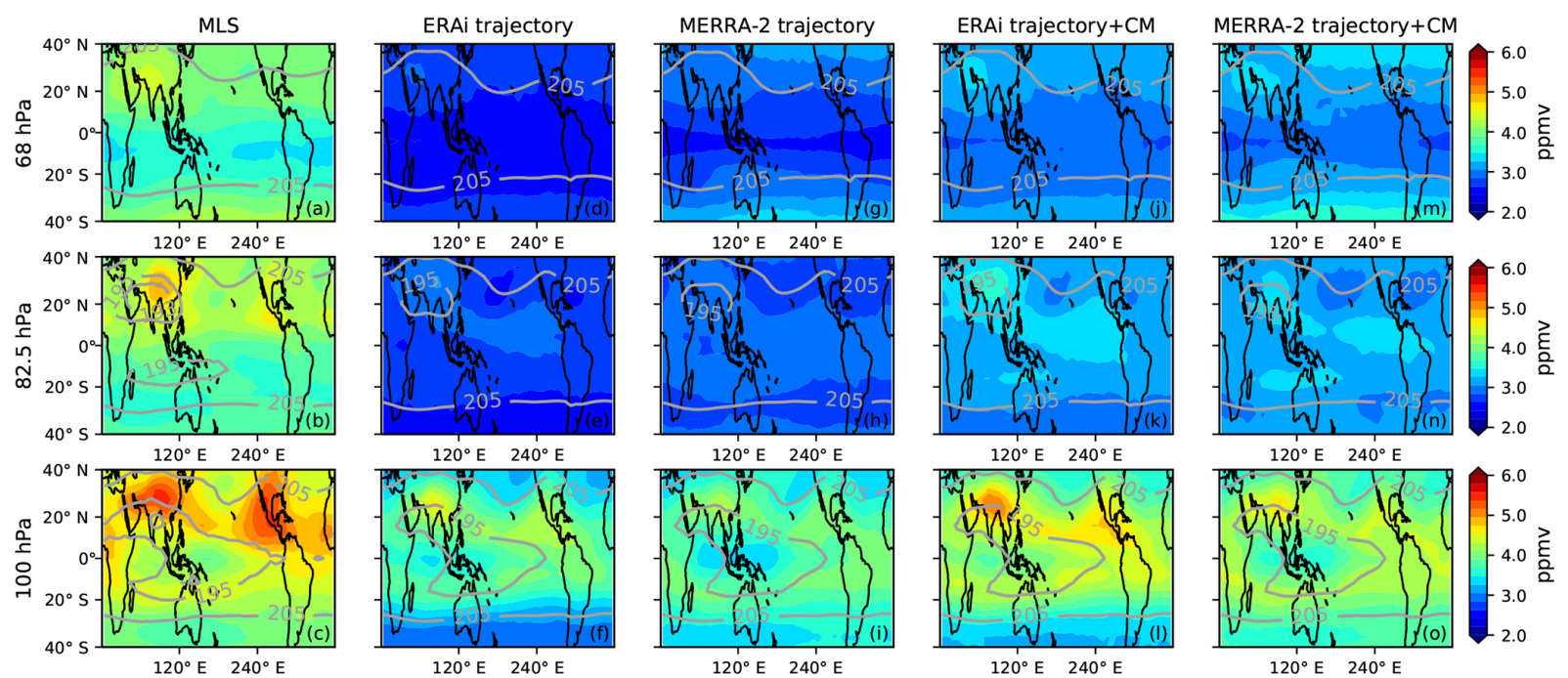

Figure 2. JJA water vapor (ppmv, color shading) and temperature (K, contour lines) between $40^{\circ} \mathrm{S}$ and $40^{\circ} \mathrm{N}$ from the (a-c) MLS; (df) ERAi trajectory model; (g-i) MERRA-2 trajectory model; (j-l) ERAi trajectory model with the cloud model; and (m-o) MERRA-2 trajectory model with the cloud model at $68 \mathrm{hPa}$ (top row), $82.5 \mathrm{hPa}$ (middle row), and $100 \mathrm{hPa}$ (bottom row).

\subsection{Ice water content from Cloud-Aerosol Lidar with Orthogonal Polarization}

The Cloud-Aerosol Lidar with Orthogonal Polarization (CALIOP) is a two-wavelength polarization elastic backscatter lidar that detects global tropospheric and lower stratospheric aerosol and cloud profiles (Hu et al., 2009; Liu et al., 2009; Vaughan et al., 2009; Winker et al., 2009, 2010; Young and Vaughan, 2009; Avery et al., 2012; Heymsfield et al., 2014). We use the CALIOP level 2 cloud profile product in version 4.2 , with a horizontal resolution of $5 \mathrm{~km}$ alongtrack and $60 \mathrm{~m}$ vertically in the TTL and LS. The CALIOP cloud ice water content (IWC) is derived from a parameter- ized function of the CALIOP $532 \mathrm{~nm}$ cloud particle extinction profiles (Avery et al., 2012; Heymsfield et al., 2014). We use the IWC from all clouds minus the IWC from thin cirrus clouds (clouds that are not opaque) above $146 \mathrm{hPa}$, which is a rough estimate of convective ice in the TTL region, since the CALIOP does not separate convective from nonconvective IWC measurements. These CALIOP IWC data, obtained between May 2008 and December 2013, are then monthly averaged onto the same horizontal and vertical grids as were used for the MLS data. 


\subsection{GEOSCCM}

We also analyze simulations from the Goddard Earth Observing System Chemistry-Climate Model (GEOSCCM). The GEOSCCM couples the GEOS-5 general circulation model (Rienecker et al., 2008; Molod et al., 2012) to a comprehensive stratospheric chemistry module (Oman and Douglass, 2014; Pawson et al., 2008). The GEOSCCM uses a single-moment cloud microphysics scheme (Bacmeister et al., 2006; Barahona et al., 2014). The run analyzed here starts in 1998 and ends in 2099 and is driven by the Representative Concentration Pathway (RCP) 6.0 greenhouse gas scenario (Van Vuuren et al., 2011) and the A1 scenario for ozonedepleting substances (World Meteorological Organization, 2011). Sea surface temperatures and sea ice concentrations were prescribed from Community Earth System Model version 1 simulations (Gent et al., 2011). The model has a horizontal resolution of $2^{\circ}$ latitude by $2.5^{\circ}$ longitude and 72 vertical levels up to the model top at $0.01 \mathrm{hPa}$ (Molod et al., 2012).

\subsection{Trajectory model}

We also use the forward, domain-filling, diabatic trajectory model described in Schoeberl and Dessler (2011) and updated in subsequent publications. The trajectory model uses 6-hourly instantaneous horizontal winds and 6-hourly average diabatic heating rates to advect parcels using the Bowman trajectory code (Bowman, 1993; Bowman and Carrie, 2002). Meteorological fields used to drive the model in this paper come from the European Centre for MediumRange Weather Forecasts (ECMWF) ERA-Interim (ERAi), the Modern-Era Retrospective analysis for Research and Applications 2 (MERRA-2) (Molod et al., 2015; Gelaro et al., 2017), and the GEOSCCM.

In this study, the trajectory model initializes 1350 parcels daily in the upper troposphere on an equal-area longitudelatitude grid covering $0-360^{\circ}$ longitude and $\pm 60^{\circ}$ latitude, and with initial water vapor mixing ratio of 200 parts per million by volume (ppmv). This value is well above saturation, so the parcels are dehydrated to saturation after the first time step of the trajectory model run. Sensitivity tests show that our results are not impacted by the initialization values.

The initialization level is at $360 \mathrm{~K}$ potential temperature, which is above the average level of zero heating $(\sim 355-$ $360 \mathrm{~K}$ ) (Fueglistaler et al., 2009) but below the tropical cold point. In the MERRA-2, the average heating rates below $\sim 365 \mathrm{~K}$ in the $\mathrm{NH}$ subtropics are negative during boreal summer (not shown), which results in parcels in that region immediately descending back to the troposphere after initialization. To deal with this problem, we initialize parcels at $360 \mathrm{~K}$ in MERRA-2 simulations. But if the local heating rate at $360 \mathrm{~K}$ is negative, we raise the initialization level to the lowest isentropic level with a positive heating rate at the same horizontal position. However, we note that the level of zero heating rate is higher $(\sim 370 \mathrm{~K})$ over the $\mathrm{NH}$ monsoon regions in MERRA-2. Releasing parcels at $\sim 370 \mathrm{~K}$ over the $\mathrm{NH}$ monsoon regions results in insufficient dehydration and a moist bias there (Schoeberl et al., 2013; Ueyama et al., 2018). To avoid this bias, we set the local initialization level to $366 \mathrm{~K}$ ( $1 \mathrm{~K}$ above the tropical average level of zero heating rate) for those parcels. At the end of each day, parcels below the $250 \mathrm{hPa}$ pressure surface or above the $5000 \mathrm{~K}$ isentrope are removed because they are considered outside of the model boundaries. We note that the parcels initialized at midlatitudes mostly descend into the troposphere.

Along each trajectory, an instant dehydration scheme is used. In this scheme, anytime the relative humidity (hereafter RH, always with respect to ice) exceeds the dehydration threshold, water vapor is instantly removed to reduce the parcel's RH to the dehydration threshold. The RH calculation uses 6-hourly temperatures linearly interpolated in time and space to parcel locations at each time step; the RH is computed using the saturation mixing ratio at that temperature (Murphy and Koop, 2005). The preset dehydration threshold is $100 \%$ RH for the ERAi trajectory runs and MERRA-2 trajectory runs. For the GEOSCCM trajectory runs, the preset dehydration threshold is $80 \% \mathrm{RH}$, since in the GEOSCCM dehydration occurs when the grid-average $\mathrm{RH}$ is around this value (Molod et al., 2012). The same parameterization for the preset RH threshold of $80 \%$ was used successfully in analyzing the water vapor interannual variability in the GEOSCCM in Dessler et al. (2016) and Ye et al. (2018). We will refer to this version as the "standard" trajectory model - another version that includes ice evaporation will be introduced later.

As an alternative to instant dehydration we can run a cloud model along the trajectory model, which is described in Schoeberl et al. (2014). The cloud model triggers ice nucleation at a prescribed nucleation RH (NRH) threshold, and the number of ice particles produced upon nucleation is proportional to the parcel cooling rate using the relationship derived by Kärcher et al. (2006). The ice mixing ratio is carried with the parcel along with the number of crystals and size. Ice crystal distribution has a single size mode that varies as the parcels grow or sublimate. Gravitational sedimentation reduces the total ice amount within the parcel. Ice crystals are assumed to be spheres which is reasonable for small crystals in the upper troposphere (Woods et al., 2018). The cloud model uses a fixed cloud geometrical thickness of $500 \mathrm{~m}$ based on the TTL cloud thickness distribution observed by CALIOP (Schoeberl et al., 2014). We also assume that ice falling out of the cloud slowly sublimates in subsaturated layers well below the cloud. The cloud model incorporates more realistic physics than the instant dehydration scheme we use in the standard trajectory model, and it produces good agreement with observational data from aircraft flights (Schoeberl et al., 2015). The physics in the cloud model has a net effect of slowing down the parcels' dehydration rate and increasing water vapor in the LS compared to the instant dehydration scheme (Schoeberl et al., 2014). 
All the trajectory model runs include methane oxidation as a water source as described in Schoeberl and Dessler (2011), but this process is unimportant in the TTL and LS. We start all trajectory models on 1 January 2000 and analyze the model results from 2005 to October 2018, so that we can compare the ERAi- and MERRA-2-driven trajectory results to the MLS observations. The GEOSCCM is a free-running model, so interannual variability of the model will not match MLS observations. We will therefore compare a multiyear average of the GEOSCCM to observations.

\section{Results}

\subsection{Impact of convective moistening on the seasonal cycle}

Figure $1 \mathrm{~d}-\mathrm{i}$ show the water vapor seasonal cycle at 100, 82.5, and $68 \mathrm{hPa}$ simulated by the standard trajectory model driven by ERAi and MERRA-2, in which dehydration is entirely driven by temperature and there is no convective influence (see Table 1 for summary of the trajectory model cases). To compare with the MLS, we averaged the trajectory water vapor fields in the vertical using the MLS averaging kernels following the instructions from Livesey et al. (2017). The trajectory models fail to produce the hemispheric asymmetry, the larger water vapor seasonal cycle in the $\mathrm{NH}$ subtropics in August-September at 100 and $82.5 \mathrm{hPa}$ (Fig. 1e$\mathrm{f}$ and $\mathrm{h}-\mathrm{i}$ ). Specifically, the ERAi and MERRA-2 trajectory models underestimate the $100 \mathrm{hPa}$ seasonal amplitude over $10-40^{\circ} \mathrm{N}$ by $0.5 \mathrm{ppmv}(24 \%)$ and $0.89 \mathrm{ppmv}$ (43\%), respectively. At $68 \mathrm{hPa}$, the trajectory models agree with the MLS that the seasonal cycle is approximately centered over the Equator, although they underpredict the MLS (Fig. 1a, d, and g). During June-July-August (JJA) (Fig. 2d-i), the trajectory models underestimate the maxima over the Asian and North American monsoon regions (Fig. 2e-f, h-i), which agrees with Ueyama et al. (2018), who also showed that the trajectory model driven by the ERAi without any convective influence fails to reproduce the boreal summer maxima. At $68 \mathrm{hPa}$, the monsoonal maxima are nearly gone (Fig. $2 \mathrm{~d}$ and g).

We also ran the ERAi and MERRA-2 simulation with the cloud model described in Sect. 2.4 operating along the trajectory model, with $100 \%$ NRH (Table 1). Note that this version of the trajectory model does not have any convective ice in it, so water vapor is still regulated entirely by TTL temperatures. Figure $1 \mathrm{j}-\mathrm{O}$ show that the cloud model produces larger water vapor values in the seasonal cycles at $100,82.5$, and $68 \mathrm{hPa}$. There is also a slight increase in the seasonal maximum poleward of $20^{\circ} \mathrm{N}$ (Fig. 11 and o) at $100 \mathrm{hPa}$. The ERAi and MERRA-2 trajectory models with the cloud model increase the $10-40^{\circ} \mathrm{N}$ seasonal amplitude at $100 \mathrm{hPa}$ by $0.1 \mathrm{ppmv}(6 \%)$ and $0.08 \mathrm{ppmv}(7 \%)$ - a small improvement compared to the instant dehydration scheme.
However, the cloud model does not help reproduce the observed hemispheric asymmetry in the seasonal cycles at 100 and $82.5 \mathrm{hPa}$ - it basically increases water vapor both north and south of the Equator. During JJA (Fig. 21 and o), the cloud model increases the $100 \mathrm{hPa}$ water vapor values over the Asian monsoon and North American monsoon regions, but there is still an underestimation compared to the MLS. We note that the NRH threshold of $100 \%$ can be too low, since previous observations showed that the NRH can be as high as $160 \%-170 \%$ in the TTL region during winter (Jensen et al., 2013). Schoeberl et al. (2016) showed that the sensitivity of trajectory-simulated water vapor to the $\mathrm{NRH}$ threshold is $0.1-0.2$ ppmv per 10 percent $\mathrm{NRH}$ and that an $\mathrm{NRH}$ threshold of $140 \%-145 \%$ in the trajectory model produces water vapor in better agreement with the MLS observations during winter. However, our result regarding the hemispheric asymmetry and boreal summer maxima agrees with Ueyama et al. (2018), who set the NRH threshold to $160 \%$, indicating that the hemispheric asymmetry is not sensitive to the choice of NRH threshold. Thus, regardless of dehydration scheme, models that regulate water vapor only through TTL temperatures and large-scale transport do not reproduce important features of the $100-82.5 \mathrm{hPa}$ water vapor seasonal cycle, including the observed hemispheric asymmetry.

Our hypothesis is that convective moistening is causing the hemispheric asymmetry in the TTL water vapor seasonal cycle. Previous analyses (e.g., Ueyama et al., 2018) have attempted to test this idea by directly incorporating observed convection into the trajectory model and then evaluating how agreement with water vapor observations improved. However, estimating convective height from passive infrared measurements is difficult, and Ueyama et al. (2018) noted that errors in the convective heights created issues in their analysis. Given this significant uncertainty in an observation-only approach, we therefore take a different tack. We perform a parallel analysis with the GEOSCCM, a model that we show below that reproduces the hemispheric asymmetry, and we will examine the causes of the asymmetry in that model and then evaluate whether we think that is what is going on the real world.

In our analysis, we first run the standard trajectory model driven by meteorology from the GEOSCCM, which, like the standard models analyzed above, uses instant dehydration to regulate water vapor exclusively through TTL temperatures. We also run a second version of the trajectory model, the "ice model", in which we add the convective moistening to the trajectory model.

The GEOSCCM outputs convective ice at every step. To add convective moistening to our trajectory model, we linearly interpolate the GEOSCCMs' 6-hourly threedimensional convective ice field to the location and time of each trajectory's time step. Then, at each time step, we assume complete evaporation of the ice into the subsaturated parcels by adding the ice water content to the parcels' water vapor - although we do not let parcels exceed the pre- 
Table 1. Summary of trajectory model cases.

\begin{tabular}{ll}
\hline Trajectory model cases & Description \\
\hline ERAi standard trajectory model & $\begin{array}{l}\text { Instant dehydration with no convec- } \\
\text { tive influence. }\end{array}$ \\
\hline MERRA-2 standard trajectory model & $\begin{array}{l}\text { Instant dehydration with no convec- } \\
\text { tive influence. }\end{array}$ \\
\hline ERAi trajectory with cloud model & $\begin{array}{l}\text { Dehydration with the cloud model, } \\
\text { but with no convective influence. }\end{array}$ \\
\hline MERRA-2 trajectory with cloud model & $\begin{array}{l}\text { Dehydration with the cloud model, } \\
\text { but with no convective influence. }\end{array}$ \\
\hline GEOSCCM ice model & $\begin{array}{l}\text { Instant dehydration with no convec- } \\
\text { tive influence. }\end{array}$ \\
\hline GEOSCCM 0.2ice model & $\begin{array}{l}\text { Instant dehydration. Convective } \\
\text { ice instantly evaporates to } \\
\text { subsaturated parcels. }\end{array}$ \\
\hline GEOSCCM ice model below $90 \mathrm{hPa}$ & $\begin{array}{l}\text { Instant dehydration. GEOSCCM } \\
\text { convective ice input is decreased } \\
\text { by } 80 \% . \text { Convective ice instantly } \\
\text { evaporates to subsaturated parcels. }\end{array}$ \\
\hline & $\begin{array}{l}\text { Instaporation above the } 90 \mathrm{hPa} \text { sur- } \\
\text { face is not allowed. }\end{array}$ \\
\hline
\end{tabular}

set RH threshold of $80 \%$. This is similar to the convective moistening scheme used by Schoeberl et al. (2014), who used MERRA anvil ice to facilitate the convective moistening in the trajectory model. After each encounter, we do not allow parcels to carry any remaining convective ice downstream as Schoeberl et al. (2014) did in one of their trajectory model settings (their ASC case). Ueyama et al. (2018) used a similar convective moistening scheme, where they saturated the column model up to the observed cloud top when a parcel's trajectory intersects a convective cloud. Because we assume instant dehydration and instant evaporation of the ice, we consider the convective moistening in our trajectory model runs to be an upper limit of the impact of convective ice evaporation on the TTL water content in the GEOSCCM (Dessler et al., 2016).

To test if GEOSCCM convective ice field is realistic, we compare GEOSCCM convective ice with CALIOP ice data (ppmv) (Figs. 3 and 4). For the CALIOP, we show IWC from all clouds minus IWC from thin cirrus clouds (not opaque), above $146 \mathrm{hPa}$, which is a rough estimate of convective ice in the TTL region, although it is almost certainly an underestimate of true convective ice amount. There is general agreement between the spatial pattern of GEOSCCM and CALIOP convective ice. However, the GEOSCCM generally produces more convective ice and higher convective top altitudes than the CALIOP. To address these problems in the GEOSCCM, we also show the GEOSCCM convective ice field reduced by
$80 \%$ (0.2ice), which brings tropical GEOSCCM convective ice into better agreement with the CALIOP values at $121 \mathrm{hPa}$ and above (Figs. 3e-f and $4 \mathrm{e}-\mathrm{f}$ ). We show below two sensitivity tests that show our results are not sensitive to the overestimation of convective IWC and convective top altitude by the GEOSCCM.

The water vapor seasonal cycles from the GEOSCCM and various GEOSCCM trajectory model runs (Table 1) are shown in Fig. 5. These have been reaveraged in the vertical using the MLS averaging kernels (Livesey et al., 2017) to facilitate comparison with MLS. We focus on the $100 \mathrm{hPa}$ level, where the hemispheric asymmetry is strongest. We note that the $100 \mathrm{hPa}$ level is in the TTL and is not strictly above the tropopause, especially in the summer $\mathrm{NH}$ monsoon region. However, processes on this level play a key role in determining stratospheric water vapor (Fueglistaler et al., 2009).

The GEOSCCM reproduces the hemispheric asymmetry seen in the MLS observations (compare Fig. 5a with Fig. 1c) and shows that during JJA the $100 \mathrm{hPa}$ water vapor maxima are located over the Asian monsoon and North American monsoon regions (compare Fig. 5b with Fig. 2c). The standard trajectory model driven by GEOSCCM meteorology, which regulates water entirely through TTL temperatures, does not reproduce the hemispheric asymmetry (Fig. 5c). That model also underestimates the JJA water vapor values in the Asian monsoon region and North American monsoon region (Fig. 5d). These results are similar to the comparison 

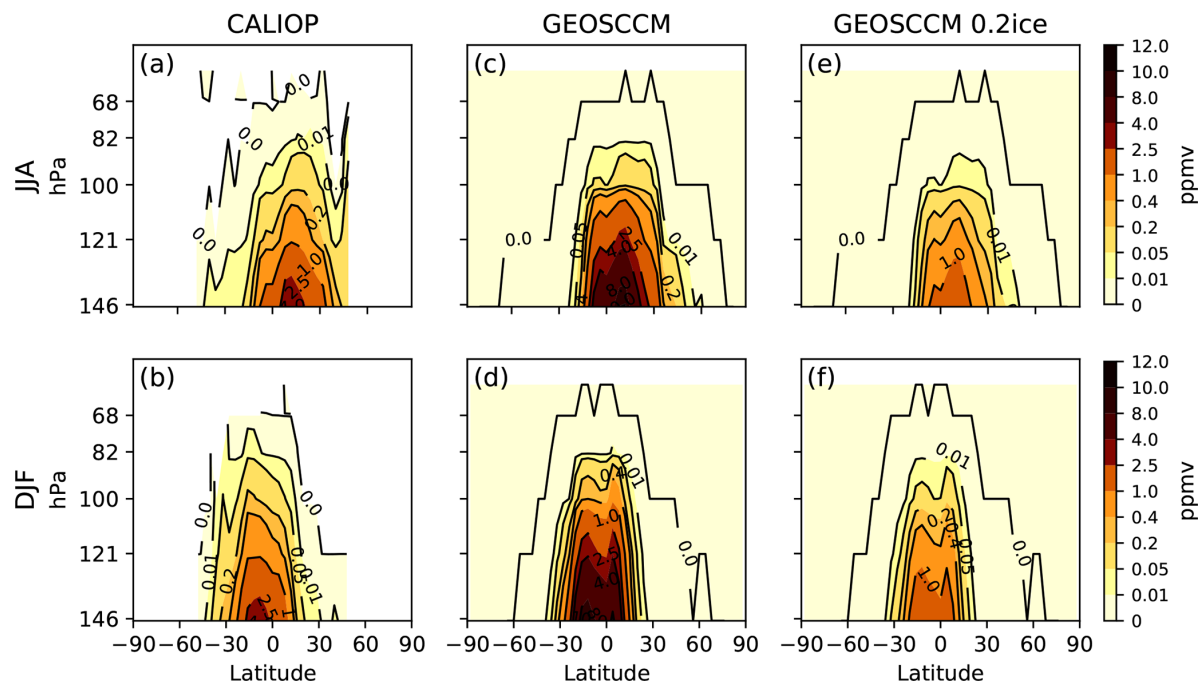

Figure 3. Zonal mean convective IWC (ppmv) from CALIOP and GEOSCCM above $146 \mathrm{hPa}$. The CALIOP ice data are averaged over JJA (a, c, e) and DJF (b, d, f) from May 2008 to December 2013. For CALIOP data (a, b), we show the ice from all clouds minus the ice from cirrus clouds, which is a rough estimate of convective ice in the TTL region. For GEOSCCM ice, we show convective ice (c, d). To better match the tropical average CALIOP ice field above $120 \mathrm{hPa}$, we decrease the GEOSCCM ice by $80 \%$ ( $0.2 \mathrm{ice})$ and show the GEOSCCM 0.2ice in panels (e) and (f). Note that we use a nonlinear color scale.
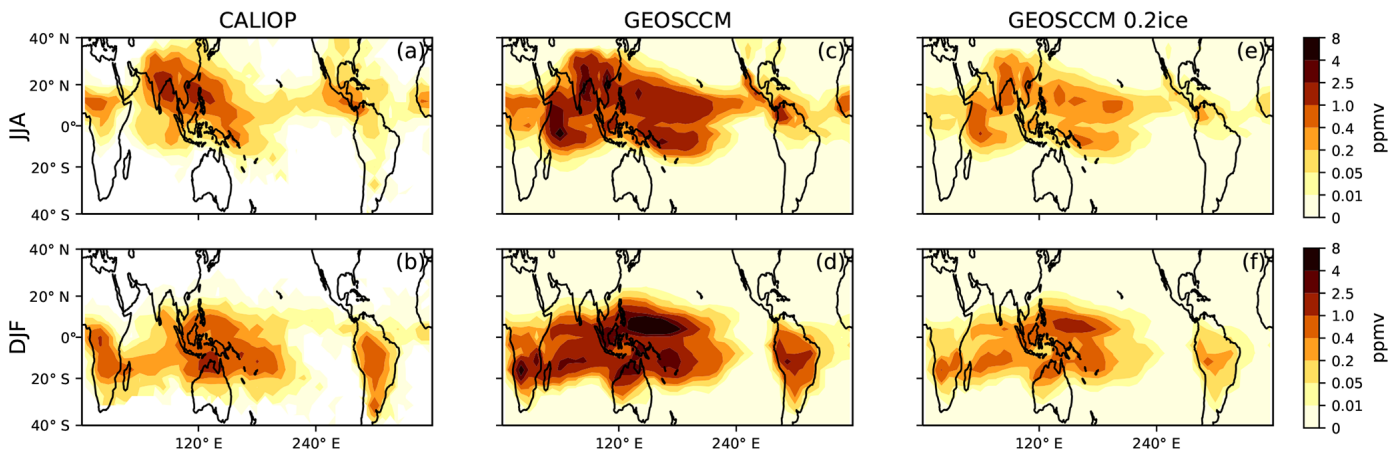

Figure 4. Same as Fig. 3 but for convective IWC (ppmv) averaged between 121 and 82.5 hPa during JJA and DJF.

between MLS and the standard trajectory models driven by ERAi and MERRA-2 (Figs. 1f, i, 2f, and i)

Figure 6 shows the $100 \mathrm{hPa}$ water vapor seasonal cycles in the NH subtropics $\left(10-40^{\circ} \mathrm{N}\right)$, deep tropics $\left(10^{\circ} \mathrm{S}-10^{\circ} \mathrm{N}\right)$, and southern hemispheric subtropics $\left(10-40^{\circ} \mathrm{S}\right)$. To aid in the comparison, we have subtracted the annual mean from each data set. The standard model generally agrees well with the GEOSCCM and MLS in the $10^{\circ} \mathrm{S}-10^{\circ} \mathrm{N}$ and 10 $40^{\circ} \mathrm{S}$ region (Fig. $6 \mathrm{~b}-\mathrm{d}$ ). This suggests that the water vapor seasonal cycle in those regions is mainly controlled by the TTL temperatures and large-scale transport and implies that other factors, including convective ice evaporation, are less important. In the $10-40^{\circ} \mathrm{N}$ region, however, the standard model does a poor job, underestimating the MLS and GEOSCCM seasonal amplitude by $1.15 \mathrm{ppmv}(55 \%)$ and 1.23 ppmv (57\%) (Fig. 6a and d).
If we add convective ice evaporation to the trajectory model, then the models show a clear hemispheric asymmetry in the $100 \mathrm{hPa}$ water vapor seasonal cycle and more pronounced seasonal maxima over the monsoon regions (Fig. 5e-h). Figure 6 shows that the ice model and the 0.2 ice model (the trajectory model where we add 0.2 ice as shown in Fig. 3e-f) produce boreal summer and autumn water vapor values in the $10-40^{\circ} \mathrm{N}$ range, which is much closer to the GEOSCCM and MLS. The ice model and the 0.2 ice model increase the $10-40^{\circ} \mathrm{N}$ seasonal maximum by $2.39 \mathrm{ppmv}(63 \%)$ and $1.65 \mathrm{ppmv}(44 \%)$, and they increase the seasonal amplitude by $1.55 \mathrm{ppmv}(169 \%)$ and $1.03 \mathrm{ppmv}$ $(112 \%)$ (Fig. 6a and d). This means convective ice evaporation is particularly important to the $100 \mathrm{hPa}$ water vapor mixing ratio in $\mathrm{NH}$ subtropics during boreal summer and autumn, thereby playing a key role in the seasonal cycle there. 

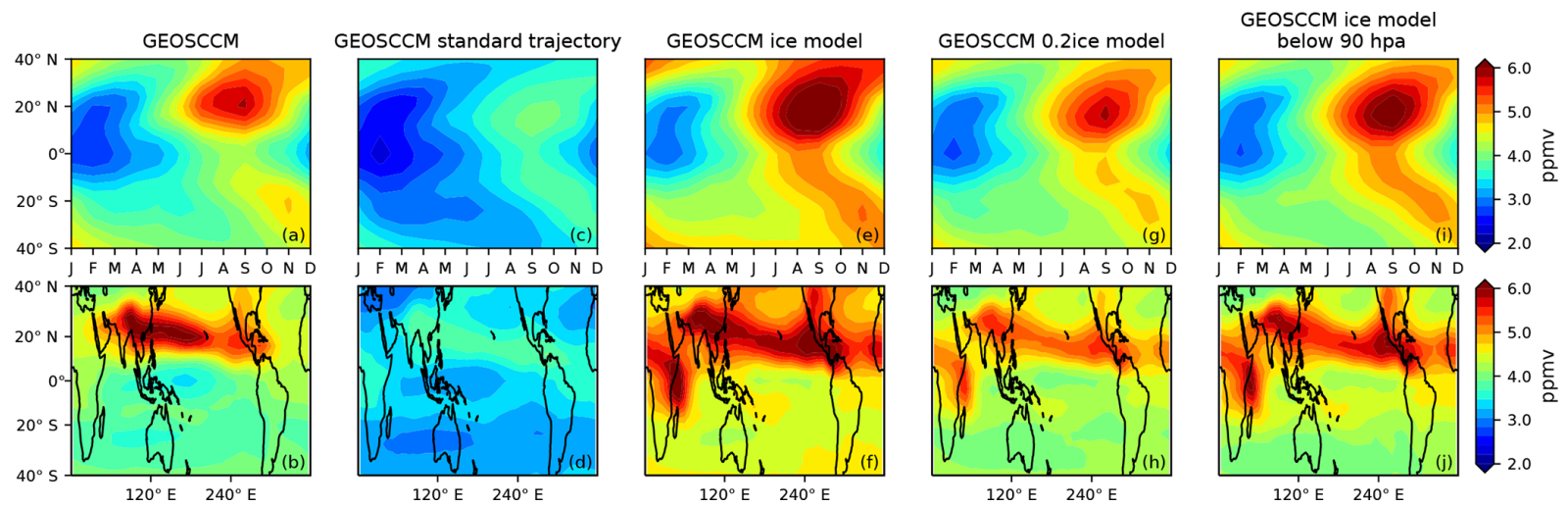

Figure 5. Top panels: zonal mean seasonal cycle of $100 \mathrm{hPa}$ water vapor (ppmv) between $40^{\circ} \mathrm{S}$ and $40^{\circ} \mathrm{N}$ from the (a) GEOSCCM, (c) GEOSCCM standard model, (e) GEOSCCM ice model, (g) GEOSCCM 0.2ice model, and (i) GEOSCCM ice model with ice below $90 \mathrm{hPa}$. Bottom panels: JJA $100 \mathrm{hPa}$ water vapor (ppmv) between $40^{\circ} \mathrm{S}$ and $40^{\circ} \mathrm{N}$ from the (b) GEOSCCM, (d) GEOSCCM standard model, (f) GEOSCCM ice model, (h) GEOSCCM 0.2ice model, and (j) GEOSCCM ice model with ice below $90 \mathrm{hPa}$.
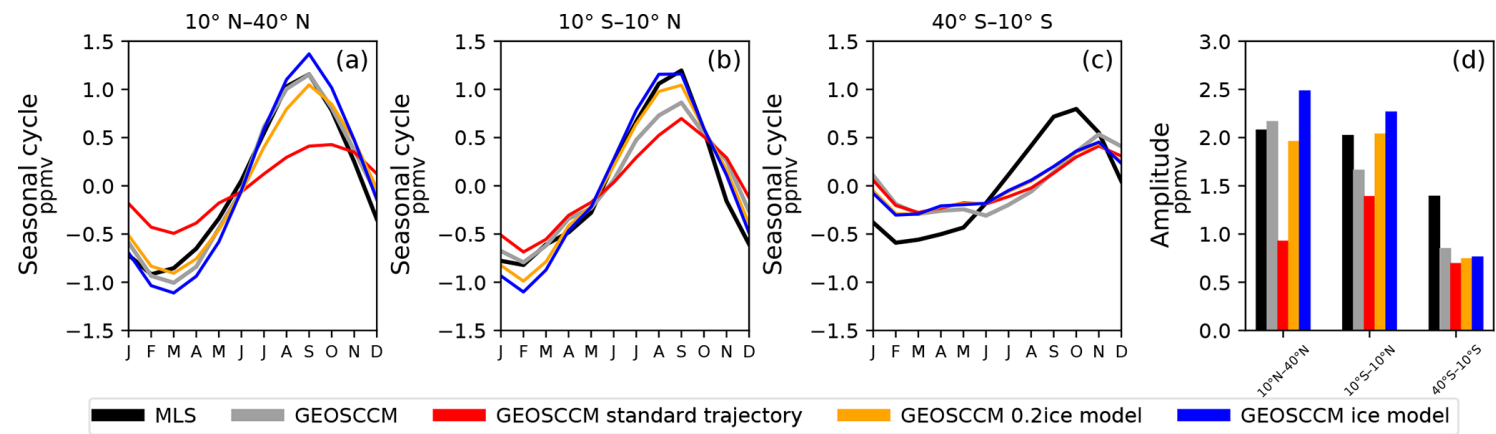

Figure 6. Seasonal cycles of water vapor at $100 \mathrm{hPa}$ averaged between (a) 10 and $40^{\circ} \mathrm{N}$, (b) $10^{\circ} \mathrm{S}$ and $10^{\circ} \mathrm{N}$, and (c) 40 and $10^{\circ} \mathrm{S}$ and their (d) seasonal amplitudes from the GEOSCCM, GEOSCCM standard model, GEOSCCM ice model, and GEOSCCM 0.2ice model. We have subtracted the annual mean from each data set.

Figure 5e shows that our ice model generates too much water vapor, which is consistent with too much IWC in the TTL. Given that the GEOSCCM's water vapor fields are reasonable (e.g., Fig. 5a vs. Fig. 1c), this further emphasizes that our instant dehydration model evaporates too much water vapor, thus yielding an upper limit of the impact of ice evaporation. It may also indicate a canceling error in the GEOSCCM: too much water from ice canceling a dehydration threshold that is too low $(80 \%)$. Clearly, more research on this question is warranted.

We ran another GEOSCCM trajectory ice model to test the sensitivity of water vapor at $100 \mathrm{hPa}$ to convective ice altitude. This was in response to our observation that convective ice in the GEOSCCM went too high into the stratosphere compared to the CALIOP (Fig. 3a vs. Fig. 3c), and we wanted to see if this influences our results. In this test run, we do not allow any ice above the $90 \mathrm{hPa}$ surface to evaporate, so that we eliminate any convective influence that is above that altitude. The zonal mean seasonal cycle and JJA water vapor at $100 \mathrm{hPa}$ from this run is shown in Fig. 5i-j. The difference between the seasonal cycles from the ice model and this test run is less than $0.3 \mathrm{ppmv}$ between $30^{\circ} \mathrm{S}$ and $30^{\circ} \mathrm{N}$. The larger moisture difference at higher latitudes comes from convective moistening in the lowermost stratosphere. However, the hemispheric asymmetry is well reproduced by this test run. We thereby conclude that the impact of convective ice evaporation on the $100 \mathrm{hPa}$ water vapor seasonal cycle is insensitive to convective ice occurrence that is too high in altitude.

These results suggest that convective ice evaporation in the TTL is important to the $100 \mathrm{hPa}$ water vapor seasonal cycle in the NH subtropics in the GEOSCCM. Combined with the fact that the GEOSCCM has reasonable water vapor and convective fields, and that our results are insensitive to errors in the IWC amount and convective altitudes in the GEOSCCM, we believe this is a plausible explanation for the hemispheric asymmetry. That plausibility is strongly supported by the lack of a competing hypothesis for the asymmetry. 

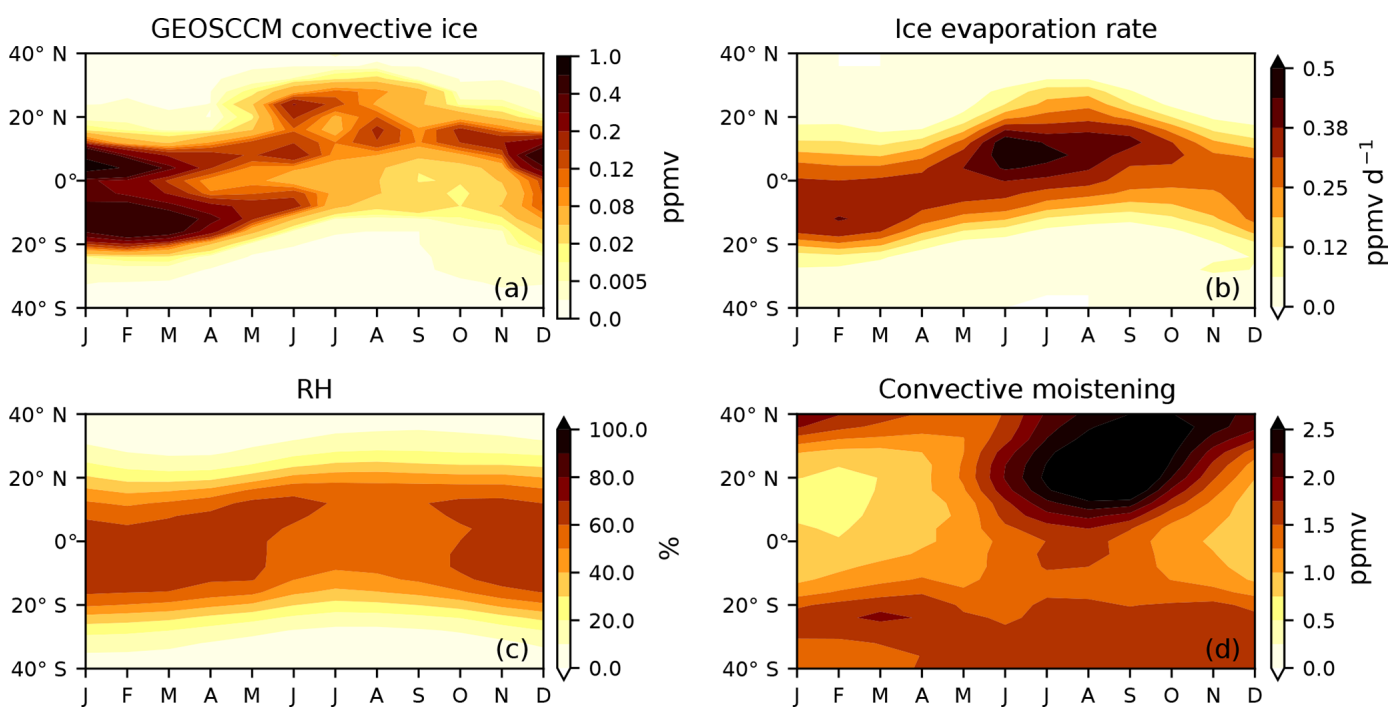

Figure 7. (a) Zonal mean seasonal cycle of $100 \mathrm{hPa}$ convective ice (ppmv) from GEOSCCM. Note that the color scale is nonlinear. (b) Zonal mean seasonal cycle of the $100 \mathrm{hPa}$ evaporation rate $\left(\mathrm{ppmv} \mathrm{d}^{-1}\right)$ from the GEOSCCM ice model. (c) Zonal mean seasonal cycle of relative humidity (\%) with respect to ice at $100 \mathrm{hPa}$ from GEOSCCM. (d) Zonal mean seasonal cycle of net convective moistening (ppmv) at $100 \mathrm{hPa}$ from the ice model. The quantity net convective moistening is the difference between water vapor values from the ice model and standard model.

\subsection{Source regions of convective ice evaporation}

Our result begs the question of which region contributes most to this convective moistening. Here we define the quantity net convective moistening to be the water vapor mixing ratio in the ice model minus that in the standard trajectory model. The net convective moistening thus represents the net water vapor added by convective ice evaporation. In this section, we investigate the regional contribution to net convective moistening in the NH subtropics in the GEOSCCM, so we do not use the MLS averaging kernels in the vertical direction, as we did in Sect. 3.1. The net convective moistening in the $\mathrm{NH}$ subtropics seasonal maximum and seasonal amplitude is therefore 2.69 and $1.68 \mathrm{ppmv}$ - slightly different from the values we show in Fig. 5. We also note that the $100 \mathrm{hPa}$ net convective moistening value in the $10^{\circ} \mathrm{S}-50^{\circ} \mathrm{N}$ domain produced by our GEOSCCM analysis during boreal summer is larger than the value of $0.6 \mathrm{ppmv}$ produced by the observational analysis of Ueyama et al.'s (2018) observational analysis. This is because the combination of the instant dehydration scheme and instant ice evaporation scheme we use in the trajectory model leads to larger net convective moistening. This also reinforces the idea that the ice model we use in this paper provides an upper limit of the impact of convective ice evaporation on the $100 \mathrm{hPa}$ water content in the GEOSCCM (Dessler et al., 2016). Thus, we view our results to mainly be qualitatively useful.

We also quantify the convective evaporation rate in the ice model. To do this, we record the location and amount of water vapor added to each parcel from ice evaporation on every time step. We then grid and average these values to produce a three-dimensional field of the ice evaporation rate (in units of ppmv $\mathrm{d}^{-1}$ ). Note that water vapor added by convection will not necessarily make it into the stratosphere - the added water vapor may be removed in subsequent dehydration events.

Figure $7 \mathrm{a}$ and $\mathrm{b}$ show that the convective evaporation rate generally follows the IWC. However, we see the highest ice evaporation rates and net convective moistening (Fig. 7d) in regions where IWC is high and RH (Fig. 7c) is low (Dessler and Sherwood, 2004). In regions where both IWC and RH are high, evaporation is suppressed, and any air that is moistened by evaporation is rapidly re-dehydrated.

To determine how evaporation in different regions contributes to the $10-40^{\circ} \mathrm{N}$ seasonal cycle, we separately track the amount of water vapor produced by evaporation in specific latitude bands. Figure 8 shows the seasonal cycle of net convective moistening at $100 \mathrm{hPa}$ averaged in the $10-40^{\circ} \mathrm{N}$ region contributed by evaporation of convective ice between 10 and $40^{\circ} \mathrm{N}$ and between $10^{\circ} \mathrm{S}$ and $10^{\circ} \mathrm{N}$. We note that, to obtain the net convective moistening and fractions contributed by specific latitude bands, we have not subtracted annual mean from the seasonal cycles in this plot like we did in Fig. 6.

During the winter (DJF), contributions from ice evaporation between $10^{\circ} \mathrm{S}$ and $10^{\circ} \mathrm{N}$ and between 10 and $40^{\circ} \mathrm{N}$ are about even, with a slightly larger contribution from $10^{\circ} \mathrm{S}-$ $10^{\circ} \mathrm{N}$. During the summertime (JJA), however, evaporation of convective ice in the $10-40^{\circ} \mathrm{N}$ region is the dominant contributor to the net convective moistening. Specifically, it contributes to $63 \%$ (1.7 ppmv) and $59 \%$ (0.9 ppmv) of the net convective moistening in the $10-40^{\circ} \mathrm{N}$ water vapor seasonal maximum (September) value and seasonal amplitude, 

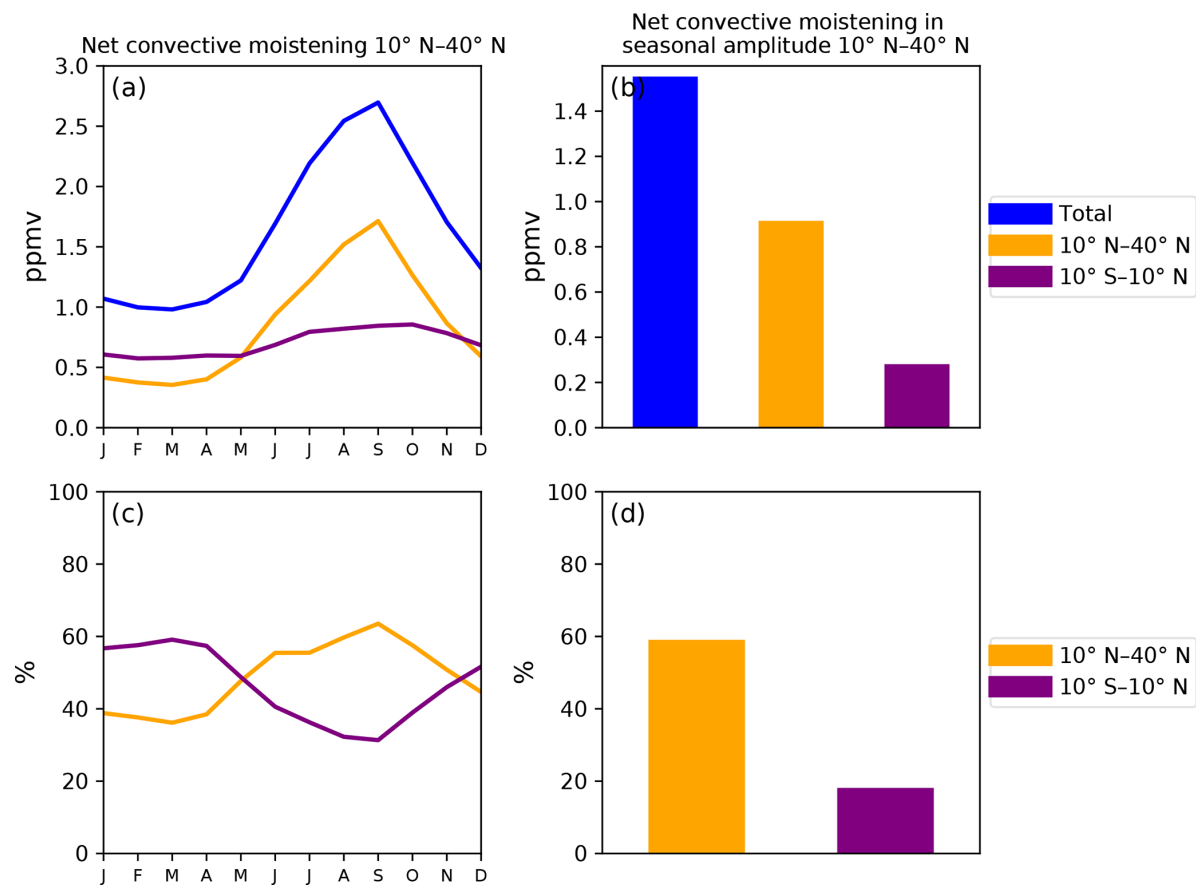

Figure 8. (a) Net convective moistening (ppmv) in the $100 \mathrm{hPa} 10-40^{\circ} \mathrm{N}$ water vapor seasonal cycle and the portions (ppmv) contributed by convective ice evaporation over $10^{\circ} \mathrm{S}-10^{\circ} \mathrm{N}$ and $10-40^{\circ} \mathrm{N}$. (b) Net convective moistening (ppmv) in the $100 \mathrm{hPa} 10-40^{\circ} \mathrm{N}$ water vapor seasonal amplitude and the portions (ppmv) contributed by convective ice evaporation over $10^{\circ} \mathrm{S}-10^{\circ} \mathrm{N}$ and $10-40^{\circ} \mathrm{N}$. (c-d) Percentage of net convective moistening in the $100 \mathrm{hPa} 10-40^{\circ} \mathrm{N}$ water vapor seasonal cycle and seasonal amplitude contributed by convective ice evaporation over $10^{\circ} \mathrm{S}-10^{\circ} \mathrm{N}$ and $10-40^{\circ} \mathrm{N}$. The percentage is net convective moistening contributed by the $10^{\circ} \mathrm{S}-10^{\circ} \mathrm{N}$ or $10-40^{\circ} \mathrm{N}$ region divided by the total net convective moistening.

respectively. Convective ice evaporation between $10^{\circ} \mathrm{S}$ and $10^{\circ} \mathrm{N}$ plays a smaller role, contributing to $31 \%(0.83 \mathrm{ppmv})$ and $17 \%(0.28 \mathrm{ppmv})$.

Next, we investigate net convective moistening in the $100 \mathrm{hPa} 10-40^{\circ} \mathrm{N}$ water vapor seasonal cycle contributed by specific regions within the $10^{\circ} \mathrm{S}-40^{\circ} \mathrm{N}$ domain. To do this, we divide the $10^{\circ} \mathrm{S}-40^{\circ} \mathrm{N}$ domain into 12 equal-area boxes. We average the net convective moistening contributed by each of these boxes using the same method we used to calculate the contribution by $10-40^{\circ} \mathrm{N}$ and $10^{\circ} \mathrm{S}-10^{\circ} \mathrm{N}$. Figure 9 shows the contribution from each box region to the net convective moistening in the $100 \mathrm{hPa} 10-40^{\circ} \mathrm{N}$ water vapor seasonal maximum value in September and the seasonal amplitude.

We find that contribution from the box regions over Southeast Asia $\left(10-40^{\circ} \mathrm{N}, 60-120^{\circ} \mathrm{E}\right)$, the subtropical western Pacific $\left(10-40^{\circ} \mathrm{N}, 120-180^{\circ} \mathrm{E}\right)$, and North America (10$\left.40^{\circ} \mathrm{N}, 120-60^{\circ} \mathrm{W}\right)$ dominate. The Southeast Asia region is most important, contributing to $20 \%(0.54 \mathrm{ppmv})$ and $20 \%$ $(0.3 \mathrm{ppmv})$ of the net convective moistening in the $10-40^{\circ} \mathrm{N}$ water vapor seasonal maximum value and seasonal amplitude, respectively. This conclusion is consistent with Ueyama et al. (2018), who showed that parcels in the $10^{\circ} \mathrm{S}-50^{\circ} \mathrm{N}$ domain at $100 \mathrm{hPa}$ are mainly hydrated by convection over Southeast Asia. Specifically, they showed that convection over the Asian monsoon region $\left(0-40^{\circ} \mathrm{N}, 40-140^{\circ} \mathrm{E}\right)$ contributes approximately $50 \%$ of the total convective moistening $\left(10^{\circ} \mathrm{S}-50^{\circ} \mathrm{N}\right)$ at $100 \mathrm{hPa}$ during August 2007 . We computed the contribution from the same domain and got a contribution of $36 \%$. The reason we produce a smaller contribution from this domain is that the GEOSCCM produces more convective ice over the tropical west Indian Ocean (Fig. 4), which results in larger convective moistening contributed by that region.

The subtropical western Pacific also contributes to the net convective moistening in the $100 \mathrm{hPa} 10-40^{\circ} \mathrm{N}$ water vapor seasonal cycle. This is due to the abundant convective ice over the subtropical west Pacific (Fig. 4b), which is likely related to the east-west oscillation of the Asian monsoon anticyclone (Pan et al., 2016; Luo et al., 2018). The North America region is less important in the ice model, contributing to $12 \%(0.3 \mathrm{ppmv})$ and $13 \%(0.21 \mathrm{ppmv})$ of the net convective moistening in the $10-40^{\circ} \mathrm{N}$ water vapor seasonal maximum value and seasonal amplitude. The GEOSCCM underestimates the observed convective ice over the North American monsoon above $120 \mathrm{hPa}$ (not shown), which may cause the contribution from the North American region to be underpredicted. 

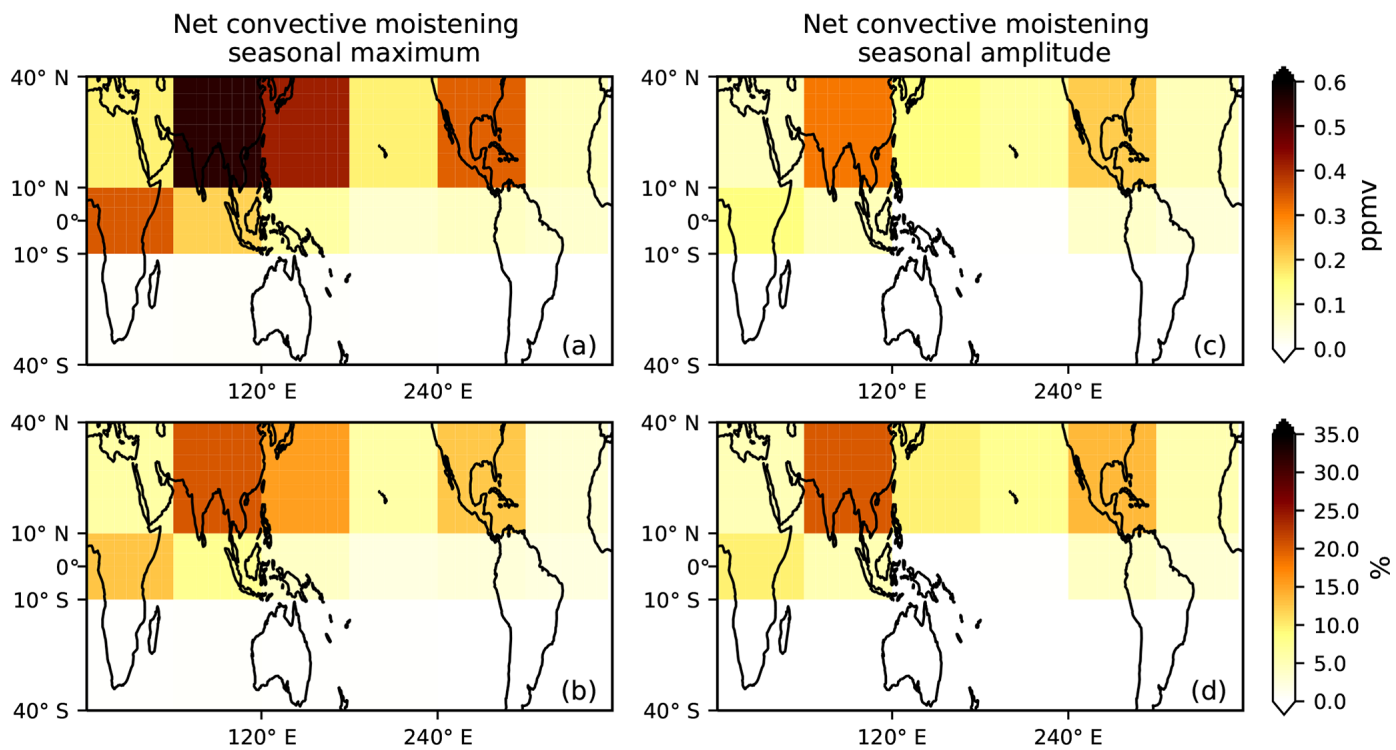

Figure 9. Portions of net convective moistening (ppmv) in the (a) maximum value and (b) seasonal amplitude of the $100 \mathrm{hPa} 10-40^{\circ} \mathrm{N}$ water vapor seasonal cycle contributed by 12 equal-area box regions between $10^{\circ} \mathrm{S}$ and $40^{\circ} \mathrm{N}$. (c-d) Same as (a) and (b) but for the percentage of net convective moistening contributed by the 12 equal-area box regions.

\section{Summary}

In this study, we investigated mechanisms that drive the seasonal cycle of water vapor in the TTL. We use a Lagrangian trajectory model (Schoeberl and Dessler, 2011) to analyze the seasonal cycle in observations of water vapor made by the Microwave Limb Sounder (MLS) (Lambert et al., 2007; Livesey et al., 2017) as well as simulated fields from the Goddard Earth Observing System Chemistry-Climate Model (GEOSCCM) (Rienecker et al., 2008; Molod et al., 2012; Pawson et al., 2008; Oman and Douglass, 2014).

Water vapor's seasonal cycle in the TTL and tropical lower stratosphere (LS), sometimes referred to as the "tape recorder", has the highest values of water vapor entering the stratosphere during $\mathrm{NH}$ summer. We confirm in both the MLS observations and in the GEOSCCM that this is mainly due to the seasonal cycle of TTL temperatures. However, closer examination of the data reveals some deficiencies in this simple picture. Both the MLS and GEOSCCM show that the water vapor seasonal cycle in the TTL has a hemispheric asymmetry, with a maximum seasonal cycle between 10 and $40^{\circ} \mathrm{N}$, despite the fact that the TTL temperature seasonal cycle is symmetric about the Equator (e.g., Rosenlof, 1997; Randel et al., 1998, 2001, and references therein). The hemispheric asymmetry is strongest at $100 \mathrm{hPa}$. Trajectory models that only regulate TTL and tropical LS water vapor using temperatures (Schoeberl and Dessler, 2011) from ERAi, MERRA-2, and GEOSCCM all produce weaker water vapor seasonal cycles between 10 and $40^{\circ} \mathrm{N}$ compared to the MLS and GEOSCCM. These indicate that the $100 \mathrm{hPa}$ seasonal os- cillation between 10 and $40^{\circ} \mathrm{N}$ is too large to be simply explained by TTL temperatures.

Recent studies suggested that evaporation of convective ice in the TTL also contributes to the amount of water vapor entering the stratosphere (Nielsen et al., 2007; Corti et al., 2008; Steinwagner et al., 2010; Dessler et al., 2016; Ueyama et al., 2015, 2018 Schoeberl et al., 2014, 2018; Ye et al., 2018). To better understand this, we analyze a chemistryclimate model where evaporation of convective ice is known to add water to the TTL (Dessler et al., 2016; Ye et al., 2018). Previous work (Ye et al., 2018) has shown that the behavior of the GEOSCCM in the TTL is reasonable and agrees well with observations. Comparisons with Cloud-Aerosol Lidar with Orthogonal Polarization (CALIOP) observations (Hu et al., 2009; Liu et al., 2009; Vaughan et al., 2009; Winker et al., 2009, 2010; Young and Vaughan, 2009; Avery et al., 2012; Heymsfield et al., 2014) show that the GEOSCCM IWC has too much ice in the TTL, but we used two sensitivity tests to show that our results are not sensitive to these disagreements.

Using a version of the trajectory model driven by GEOSCCM meteorology that includes evaporation of GEOSCCM convective ice, we obtained a more accurately simulated seasonal cycle of the $100 \mathrm{hPa}$ water vapor between 10 and $40^{\circ} \mathrm{N}$ and the hemispheric asymmetry compared to the GEOSCCM. We showed results where the GEOSCCM's IWC is reduced to $20 \%$ of the original value, and that did not affect our conclusions. In addition, our results are also not sensitive to GEOSCCM putting convective ice too high in altitude (above $90 \mathrm{hPa}$ ). In these runs, adding convective ice to the trajectory model increases the $100 \mathrm{hPa} 10-40^{\circ} \mathrm{N}$ seasonal maximum by 1.65 ppmv ( $44 \%$ ) and increases the seasonal 
amplitude by 1.03 ppmv ( $112 \%)$. We note that our estimate of convective moistening in the NH subtropical seasonal cycle in the GEOSCCM is larger than the value produced by previous studies based on observations (e.g., Ueyama et al., 2018). This could be due to overestimates of IWC by the GEOSCCM or because the instant dehydration scheme and instant ice evaporation scheme we use lead to a greater convective impact on water vapor values overall. Therefore we regard our results as providing insight for understanding the observations, but we caution against assuming that the numbers we calculate for ice evaporation in the GEOSCCM are quantitatively accurate estimates of our atmosphere's values.

The majority of the convective moistening at $100 \mathrm{hPa}$ and between 10 and $40^{\circ} \mathrm{N}$ is contributed by convective ice evaporation in the $10-40^{\circ} \mathrm{N}$ latitudinal range during boreal summer. The maximum convective ice evaporation in this region is due to available convective ice and relative humidity low enough to allow it to evaporate (Dessler and Sherwood, 2004). Ice evaporation between 10 and $40^{\circ} \mathrm{N}$ contributes to $63 \%$ and $59 \%$ of the net convective moistening in the $100 \mathrm{hPa} 10-40^{\circ} \mathrm{N}$ water vapor seasonal maximum value and seasonal amplitude. Between 10 and $40^{\circ} \mathrm{N}$, the Asian monsoon region plays the most important role in convective moistening by ice evaporation. Convective ice evaporation in other regions, including the deep tropics between $10^{\circ} \mathrm{S}$ and $10^{\circ} \mathrm{N}$, has a smaller influence in $100 \mathrm{hPa}$ water vapor between 10 and $40^{\circ} \mathrm{N}$. However, since the GEOSCCM underestimates the observed convective ice over the North American monsoon above $120 \mathrm{hPa}$ (not shown), it is likely that this causes an underestimation of the moistening effect of convective ice over the North American region. Previous studies showed that the ratio of isotopic water vapor (HDO), an indicator of sublimation of convective ice and in-mixing (e.g., Dessler et al., 2007; Hanisco et al., 2007; Randel et al., 2012), enhances over the American monsoon region during boreal summer, suggesting more convective ice evaporation there (Randel et al., 2012). This paper does not discuss the HDO issue, and more work needs to be done in the future.

To summarize, we find that TTL temperature variations alone cannot explain the seasonal cycle of water vapor at $100 \mathrm{hPa}$ in MLS observations over the NH subtropics, $10-40^{\circ} \mathrm{N}$ (although temperature does explain the seasonal cycle in the tropics, $10^{\circ} \mathrm{S}-10^{\circ} \mathrm{N}$; and southern subtropics, $10-40^{\circ} \mathrm{S}$ ). To try to understand the other mechanisms at work, we analyze a chemistry-climate model, the GEOSCCM, which reproduces the MLS observations and has been shown to accurately simulate the TTL. We find that, in the GEOSCCM, evaporation of convective ice in the TTL is responsible for the larger seasonal cycle in the $100 \mathrm{hPa} \mathrm{NH}$ subtropics. We therefore conclude that evaporation of convective ice in the TTL, mainly in boreal summer, is the most likely explanation for the observed larger seasonal cycle in the NH subtropics. We concur that the seasonal cycle of the TTL temperatures is the major driver of the seasonal cycle of water vapor entering the stratosphere, but we find that the contribution from evaporation of convective ice fills in more details of this simple picture. Our findings emphasize the need to better understand and quantify the magnitude and spatial pattern of convective ice evaporation in the TTL.

Data availability. The water vapor observed by MLS is available at https://mls.jpl.nasa.gov/ (Lambert et al., 2015). The CALIOP data were obtained from the NASA Langley Research Center Atmospheric Science Data Center, available at https://eosweb.larc.nasa.gov/ (Winker, 2018). The MERRA2 meteorological fields are available at https://disc.gsfc.nasa. gov/ (GMAO, 2015). The ERA-Interim meteorological fields provided courtesy of ECMWF are available at https://www. ecmwf.int/en/forecasts/datasets/ (Dee et al., 2011, last access: December 2018). The monthly water vapor data from the GEOSCCM, GEOSCCM trajectory model, ERAi trajectory model, and MERRA-2 trajectory model simulations are available at https://doi.org/10.5281/zenodo.3543818 (Wang et al., 2019). The codes for this paper are available on GitHub at https://github.com/ xunwang 15/Code-and-data-for-acp-Wang-et-al-2019 (Wang 2019, last access: November 2019).

Author contributions. XW performed the analysis and wrote the original draft. AED provided the conceptualization, guidance, and editing. MRS and TW contributed to the trajectory model code, methodology, discussion, and editing. WY contributed to the methodology and discussion.

Competing interests. The authors declare that they have no conflict of interest.

Acknowledgements. We would like to thank Luke Oman for providing the GEOSCCM meteorological fields used in this study.

Financial support. This work was supported by NASA grants NNX16AM15G and 80NSSC18K0134, both to Texas A\&M University.

Review statement. This paper was edited by Timothy J. Dunkerton and reviewed by Stephan Fueglistaler and William Read.

\section{References}

Avery, M., Winker, D., Heymsfield, A., Vaughan, M., Young, S., $\mathrm{Hu}, \mathrm{Y}$., and Trepte, C.: Cloud ice water content retrieved from the CALIOP space-based lidar, Geophys. Res. Lett., 39, L05808, https://doi.org/10.1029/2011gl050545, 2012.

Avery, M. A., Davis, S. M., Rosenlof, K. H., Ye, H., and Dessler, A. E.: Large anomalies in lower stratospheric water vapour and ice during the 2015-2016 El Niño, Nat. Geosci., 10, 405-409, https://doi.org/10.1038/ngeo2961, 2017. 
Bacmeister, J. T., Suarez, M. J., and Robertson, F. R.: Rain Reevaporation, Boundary Layer-Convection Interactions, and Pacific Rainfall Patterns in an AGCM, J. Atmos. Sci., 63, 3383-3403, https://doi.org/10.1175/JAS3791.1, 2006.

Bannister, R. N., O’Neill, A., Gregory, A. R., and Nissen, K. M.: The role of the south-east Asian monsoon and other seasonal features in creating the 'tape-recorder' signal in the Unified Model, Q. J. Roy. Meteorol. Soc., 130, 1531-1554, https://doi.org/10.1256/qj.03.106, 2004.

Barahona, D., Molod, A., Bacmeister, J., Nenes, A., Gettelman, A., Morrison, H., Phillips, V., and Eichmann, A.: Development of two-moment cloud microphysics for liquid and ice within the NASA Goddard Earth Observing System Model (GEOS-5), Geosci. Model Dev., 7, 1733-1766, https://doi.org/10.5194/gmd7-1733-2014, 2014.

Bian, J., Pan, L. L., Paulik, L., Vömel, H., Chen, H., and Lu, D.: In situ water vapor and ozone measurements in Lhasa and Kunming during the Asian summer monsoon, Geophys. Res. Lett., 39, L19808, https://doi.org/10.1029/2012GL052996, 2012.

Bowman, K. P.: Large-scale isentropic mixing properties of the Antarctic polar vortex from analyzed winds, J. Geophys. Res.Atmos., 98, 23013-23027, https://doi.org/10.1029/93JD02599, 1993.

Bowman, K. P. and Carrie, G. D.: The mean-meridional transport circulation of the troposphere in an idealized (GCM), J. Atmos. Sci., 59, 1502-1514, https://doi.org/10.1175/15200469(2002)059<1502:TMMTCO>2.0.CO;2, 2002.

Brewer, A. W.: Evidence for a world circulation provided by the measurements of helium and water vapour distribution in the stratosphere, Q. J. Roy. Meteorol. Soc., 75, 351-363, https://doi.org/10.1002/qj.49707532603, 1949.

Corti, T., Luo, B. P., de Reus, M., Brunner, D., Cairo, F., Mahoney, M. J., Martucci, G., Matthey, R., Mitev, V., dos Santos, F. H., Schiller, C., Shur, G., Sitnikov, N. M., Spelten, N., Vössing, H. J., Borrmann, S., and Peter, T.: Unprecedented evidence for deep convection hydrating the tropical stratosphere, Geophys. Res. Lett., 35, L10810, https://doi.org/10.1029/2008GL033641, 2008.

Dee, D. P., Uppala, S. M., Simmons, A. J., Berrisford, P., Poli, P., Kobayashi, S., Andrae, U., Balmaseda, M. A., Balsamo, G., Bauer, P., Bechtold, P., Beljaars, A. C. M., van de Berg, L., Bidlot, J., Bormann, N., Delsol, C., Dragani, R., Fuentes, M., Geer, A. J., Haimberger, L., Healy, S. B., Hersbach, H., Hólm, E. V., Isaksen, L., Kållberg, P., Köhler, M., Matricardi, M., McNally, A. P., Monge-Sanz, B. M., Morcrette, J.-J., Park, B.-K., Peubey, C., de Rosnay, P., Tavolato, C., Thépaut, J.-N., and Vitart, F.: The ERA-Interim reanalysis: configuration and performance of the data assimilation system, Q. J. Roy. Meteorol. Soc., 137, 553597. https://doi.org/10.1002/qj.828, 2011.

Dessler, A. E. and Sherwood, S. C.: Effect of convection on the summertime extratropical lower stratosphere, J. Geophys. Res.Atmos., 109, D23301, https://doi.org/10.1029/2004JD005209, 2004

Dessler, A. E., Hanisco, T. F., and Fueglistaler, S.: Effects of convective ice lofting on $\mathrm{H}_{2} \mathrm{O}$ and $\mathrm{HDO}$ in the tropical tropopause layer, J. Geophys. Res., 112, D18309, https://doi.org/10.1029/2007JD008609, 2007.

Dessler, A. E., Ye, H., Wang, T., Schoeberl, M. R., Oman, L. D., Douglass, A. R., Butler, A. H., Rosenlof, K. H.,
Davis, S. M., and Portmann, R. W.: Transport of ice into the stratosphere and the humidification of the stratosphere over the 21st century, Geophys. Res. Lett., 43, 2323-2329, https://doi.org/10.1002/2016GL067991, 2016.

Dethof, A., O’Neill, A., Slingo, J. M., and Smit, H. G. J.: A mechanism for moistening the lower stratosphere involving the Asian summer monsoon, Q. J. Roy. Meteorol. Soc., 125, 1079-1106, https://doi.org/10.1002/qj.1999.49712555602, 1999.

Dvortsov, V. L. and Solomon, S.: Response of the stratospheric temperatures and ozone to past and future increases in stratospheric humidity, J. Geophys. Res.-Atmos., 106, 7505-7514, https://doi.org/10.1029/2000JD900637, 2001.

Fu, R., Hu, Y., Wright, J. S., Jiang, J. H., Dickinson, R. E., Chen, M., Filipiak, M., Read, W. G., Waters, J. W., and Wu, D. L.: Short circuit of water vapor and polluted air to the global stratosphere by convective transport over the Tibetan Plateau, P. Natl. Acad. Sci. USA, 103, 5664-5669, https://doi.org/10.1073/pnas.0601584103, 2006.

Fueglistaler, S.: Stratospheric water vapor predicted from the Lagrangian temperature history of air entering the stratosphere in the tropics, J. Geophys. Res., 110, D08107, https://doi.org/10.1029/2004JD005516, 2005.

Fueglistaler, S., Dessler, A. E., Dunkerton, T. J., Folkins, I., Fu, Q., and Mote, P. W.: Tropical tropopause layer, Rev. Geophys., 47, 1-31, https://doi.org/10.1029/2008RG000267, 2009.

Gelaro, R., McCarty, W., Suárez, M. J., Todling, R., Molod, A., Takacs, L., Randles, C. A., Darmenov, A., Bosilovich, M. G., Reichle, R., Wargan, K., Coy, L., Cullather, R., Draper, C., Akella, S., Buchard, V., Conaty, A., da Silva, A. M., Gu, W., Kim, G.K., Koster, R., Lucchesi, R., Merkova, D., Nielsen, J. E., Partyka, G., Pawson, S., Putman, W., Rienecker, M., Schubert, S. D., Sienkiewicz, M., and Zhao, B.: The Modern-Era Retrospective Analysis for Research and Applications, Version 2 (MERRA-2), J. Climate, 30, 5419-5454, https://doi.org/10.1175/JCLI-D-160758.1, 2017.

Gent, P. R., Danabasoglu, G., Donner, L. J., Holland, M. M., Hunke, E. C., Jayne, S. R., Lawrence, D. M., Neale, R. B., Rasch, P. J., Vertenstein, M., Worley, P. H., Yang, Z.-L., and Zhang, M.: The Community Climate System Model Version 4, J. Climate, 24 4973-4991, https://doi.org/10.1175/2011JCLI4083.1, 2011.

Gettelman, A., Kinnison, D. E., Dunkerton, T. J., and Brasseur, G. P.: Impact of monsoon circulations on the upper troposphere and lower stratosphere, J. Geophys. Res.-Atmos., 109, D22101, https://doi.org/10.1029/2004JD004878, 2004.

Global Modeling and Assimilation Office (GMAO): MERRA2 inst6_3d_ana_Nv: 3d,6-Hourly, Instantaneous,Model-Level, Analysis, Analyzed Meteorological Fields V5.12.4, Goddard Earth Sciences Data and Information Services Center (GES DISC), Greenbelt, MD, USA, last access: 21 November 2018, https://doi.org/10.5067/IUUF4WB9FT4W, 2015.

Hanisco, T. F., Moyer, E. J., Weinstock, E. M., St. Clair, J. M., Sayres, D. S., Smith, J. B., Lockwood, R., Anderson, J. G., Dessler, A. E., Keutsch, F. N., Spackman, J. R., Read, W. G., and Bui, T. P.: Observations of deep convective influence on stratospheric water vapor and its isotopic composition, Geophys. Res. Lett., 34, L04814, https://doi.org/10.1029/2006GL027899, 2007.

Heymsfield, A., Winker, D., Avery, M., Vaughan, M., Diskin, G., Deng, M., Mitev, V., and Matthey, R.: Relationships between Ice Water Content and Volume Extinction Coefficient from In Situ 
Observations for Temperatures from $0^{\circ}$ to $-86^{\circ} \mathrm{C}$ : Implications for Spaceborne Lidar Retrievals, J. Appl. Meteorol. Climatol., 53, 479-505, https://doi.org/10.1175/JAMC-D-13-087.1, 2014.

Holton, J. R., Haynes, P. H., McIntyre, M. E., Douglass, A. R., Rood, R. B., and Pfister, L.: Stratosphere-troposphere exchange, Rev. Geophys., 33, 403, https://doi.org/10.1029/95RG02097, 1995.

Hu, Y., Winker, D., Vaughan, M., Lin, B., Omar, A., Trepte, C., Flittner, D., Yang, P., Nasiri, S. L., Baum, B., Holz, R., Sun, W., Liu, Z., Wang, Z., Young, S., Stamnes, K., Huang, J., and Kuehn, R.: CALIPSO/CALIOP Cloud Phase Discrimination Algorithm, J. Atmos. Ocean. Tech., 26, 2293-2309, https://doi.org/10.1175/2009JTECHA1280.1, 2009.

Jackson, D. R., Driscoll, S. J., Highwood, E. J., Harries, J. E., and Russell, J. M.: Troposphere to stratosphere transport at low latitudes as studies using HALOE observations of water vapour 1992-1997, Q. J. Roy. Meteorol. Soc., 124, 169-192, https://doi.org/10.1002/qj.49712454508, 1998.

James, R., Bonazzola, M., Legras, B., Surbled, K., and Fueglistaler, S.: Water vapor transport and dehydration above convective outflow during Asian monsoon, Geophys. Res. Lett., 35, L20810, https://doi.org/10.1029/2008GL035441, 2008.

Jensen, E. J., Diskin, G., Lawson, R. P., Lance, S., Bui, T. P., Hlavka, D., McGill, M., Pfister, L., Toon, O. B., and Gao, R.: Ice nucleation and dehydration in the Tropical Tropopause Layer, P. Natl. Acad. Sci. USA, 110(6), 2041-2046, https://doi.org/10.1073/pnas.1217104110, 2013.

Kärcher, B., Hendricks, J., and Lohmann, U.: Physically based parameterization of cirrus cloud formation for use in global atmospheric models, J. Geophys. Res., 111, D01205, https://doi.org/10.1029/2005JD006219, 2006.

Lambert, A., Read, W. G., Livesey, N. J., Santee, M. L., Manney, G. L., Froidevaux, L., Wu, D. L., Schwartz, M. J., Pumphrey, H. C., Jimenez, C., Nedoluha, G. E., Cofield, R. E., Cuddy, D. T., Daffer, W. H., Drouin, B. J., Fuller, R. A., Jarnot, R. F., Knosp, B. W., Pickett, H. M., Perun, V. S., Snyder, W. V, Stek, P. C., Thurstans, R. P., Wagner, P. A., Waters, J. W., Jucks, K. W., Toon, G. C., Stachnik, R. A., Bernath, P. F., Boone, C. D., Walker, K. A., Urban, J., Murtagh, D., Elkins, J. W., and Atlas, E.: Validation of the Aura Microwave Limb Sounder middle atmosphere water vapor and nitrous oxide measurements, J. Geophys. Res.-Atmos., 112, D24S36, https://doi.org/10.1029/2007JD008724, 2007.

Lambert, A., Read, W., and Livesey, N.: MLS/Aura Level 2 Water Vapor $\left(\mathrm{H}_{2} \mathrm{O}\right)$ Mixing Ratio V004, Goddard Earth Sciences Data and Information Services Center (GES DISC), Greenbelt, MD, USA, last access: 30 November 2018, https://doi.org/10.5067/Aura/MLS/DATA2009, 2015.

Liu, Z., Vaughan, M., Winker, D., Kittaka, C., Getzewich, B., Kuehn, R., Omar, A., Powell, K., Trepte, C., and Hostetler, C.: The CALIPSO Lidar Cloud and Aerosol Discrimination: Version 2 Algorithm and Initial Assessment of Performance, J. Atmos. Ocean. Tech., 26, 1198-1213, https://doi.org/10.1175/2009JTECHA1229.1, 2009.

Livesey, N. J., Read, W. G., Wagner, P. A., Froidevaux, L., Lambert, A., Manney, G. L., Millán-Valle, L. F., Pumphrey, H. C., Santee, M. L., Schwartz, M. J., Wang, S., Fuller, R. A., Jarnot, R. F., Knosp, B. W., and Martinez, E.: Earth Observing System (EOS) Aura Microwave Limb Sounder (MLS), Version 4.2x Level 2 data quality and description document, Tech. Rep. JPL D-33509,
Tech. Rep. version 4.2x-3.0, NASA Jet Propulsion Laboratory, 2017.

Luo, J., Pan, L. L., Honomichl, S. B., Bergman, J. W., Randel, W. J., Francis, G., Clerbaux, C., George, M., Liu, X., and Tian, W.: Space-time variability in UTLS chemical distribution in the Asian summer monsoon viewed by limb and nadir satellite sensors, Atmos. Chem. Phys., 18, 12511-12530, https://doi.org/10.5194/acp-18-12511-2018, 2018.

Molod, A., Takacs, L., Suarez, M., Bacmeister, J., Song, I.-S., and Eichmann, A.: The GEOS-5 atmospheric general circulation model: Mean climate and development from MERRA to Fortuna, Technical Report Series on Global Modeling and Data Assimilation Volume 28, NASA Goddard Space Flight Center, 2012.

Molod, A., Takacs, L., Suarez, M., and Bacmeister, J.: Development of the GEOS-5 atmospheric general circulation model: evolution from MERRA to MERRA2, Geosci. Model Dev., 8, 1339-1356, https://doi.org/10.5194/gmd-8-1339-2015, 2015.

Mote, P. W., Rosenloh, K. H., Holton, J. R., Harwood, R. S., and Waters, J. W.: Seasonal variations of water vapor in the tropical lower stratosphere, Geophys. Res. Lett., 22, 1093-1096, https://doi.org/10.1029/95GL01234, 1995.

Mote, P. W., Rosenlof, K. H., McIntyre, M. E., Carr, E. S., Gille, J. C., Holton, J. R., Kinnersley, J. S., Pumphrey, H. C., Russell III, J. M., and Waters, J. W.: An atmospheric tape recorder: The imprint of tropical tropopause temperatures on stratospheric water vapor, J. Geophys. Res., 101, 3989-4006, https://doi.org/10.1029/95JD03422, 1996.

Moyer, E. J., Irion, F. W., Yung, Y. L., and Gunson, M. R.: ATMOS stratospheric deuterated water and implications for tropospherestratosphere transport, Geophys. Res. Lett., 23, 2385-2388, https://doi.org/10.1029/96GL01489, 1996.

Murphy, D. M. and Koop, T.: Review of the vapour pressures of ice and supercooled water for atmospheric applications, Q. J. Roy. Meteorol. Soc., 131, 1539-1565, https://doi.org/10.1256/qj.04.94, 2005.

Nielsen, J. K., Larsen, N., Cairo, F., Di Donfrancesco, G., Rosen, J. M., Durry, G., Held, G., and Pommereau, J. P.: Solid particles in the tropical lowest stratosphere, Atmos. Chem. Phys., 7, 685695, https://doi.org/10.5194/acp-7-685-2007, 2007.

Oman, L. D. and Douglass, A. R.: Improvements in total column ozone in GEOSCCM and comparisons with a new ozonedepleting substances scenario, J. Geophys. Res.-Atmos., 119, 5613-5624, https://doi.org/10.1002/2014JD021590, 2014.

Pan, L., Solomon, S., Randel, W., Lamarque, J.-F., Hess, P., Gille, J., Chiou, E.-W., and McCormick, M. P.: Hemispheric asymmetries and seasonal variations of the lowermost stratospheric water vapor and ozone derived from SAGE II data, J. Geophys. Res.Atmos., 102, 28177-28184, https://doi.org/10.1029/97JD02778, 1997.

Pan, L. L., Hintsa, E. J., Stone, E. M., Weinstock, E. M., and Randel, W. J.: The seasonal cycle of water vapor and saturation vapor mixing ratio in the extratropical lowermost stratosphere, J. Geophys. Res.-Atmos., 105, 26519-26530, https://doi.org/10.1029/2000JD900401, 2000.

Pan, L. L., Honomichl, S. B., Kinnison, D. E., Abalos, M., Randel, W. J., Bergman, J. W., and Bian, J.: Transport of chemical tracers from the boundary layer to stratosphere associated with the dynamics of the Asian sum- 
mer monsoon, J. Geophys. Res.-Atmos., 121, 14159-14174, https://doi.org/10.1002/2016JD025616, 2016.

Park, M., Randel, W. J., Kinnison, D. E., Garcia, R. R., and Choi, W.: Seasonal variation of methane, water vapor, and nitrogen oxides near the tropopause: Satellite observations and model simulations, J. Geophys. Res.-Atmos., 109, D03302, https://doi.org/10.1029/2003JD003706, 2004.

Park, M., Randel, W. J., Gettelman, A., Massie, S. T., and Jiang, J. H.: Transport above the Asian summer monsoon anticyclone inferred from Aura Microwave Limb Sounder tracers, J. Geophys. Res.-Atmos., 112, D16309, https://doi.org/10.1029/2006JD008294, 2007.

Pawson, S., Stolarski, R. S., Douglass, A. R., Newman, P. A., Nielsen, J. E., Frith, S. M., and Gupta, M. L.: Goddard Earth Observing System chemistry-climate model simulations of stratospheric ozone-temperature coupling between 1950 and 2005, J. Geophys. Res., 113, D12103, https://doi.org/10.1029/2007JD009511, 2008.

Ploeger, F., Günther, G., Konopka, P., Fueglistaler, S., Müller, R., Hoppe, C., Kunz, A., Spang, R., Grooß, J.-U., and Riese, M.: Horizontal water vapor transport in the lower stratosphere from subtropics to high latitudes during boreal summer, J. Geophys. Res.-Atmos., 118, 8111-8127, https://doi.org/10.1002/jgrd.50636, 2013.

Randel, W. J. and Park, M.: Deep convective influence on the Asian summer monsoon anticyclone and associated tracer variability observed with Atmospheric Infrared Sounder (AIRS), J. Geophys. Res., 111, D12314, https://doi.org/10.1029/2005JD006490, 2006.

Randel, W. J., Wu, F., Russell, J. M., Roche, A., and Waters, J. W.: Seasonal Cycles and QBO Variations in Stratospheric $\mathrm{CH}_{4}$ and $\mathrm{H}_{2} \mathrm{O}$ Observed in UARSHALOE Data, J. Atmos. Sci., 55, 163-185, https://doi.org/10.1175/15200469(1998)055<0163:Scaqvi>2.0.Co;2, 1998.

Randel, W. J., Wu, F., Gettelman, A., Russell, J. M., Zawodny, J. M., and Oltmans, S. J.: Seasonal variation of water vapor in the lower stratosphere observed in Halogen Occultation Experiment data, J. Geophys. Res.-Atmos., 106, 14313-14325, https://doi.org/10.1029/2001jd900048, 2001.

Randel, W. J., Moyer, E., Park, M., Jensen, E., Bernath, P., Walker, K., and Boone, C.: Global variations of $\mathrm{HDO}$ and $\mathrm{HDO} / \mathrm{H}_{2} \mathrm{O}$ ratios in the upper troposphere and lower stratosphere derived from ACE-FTS satellite measurements, J. Geophys. Res.-Atmos., 117, D06303, https://doi.org/10.1029/2011JD016632, 2012.

Randel, W. J., Zhang, K., and Fu, R.: What controls stratospheric water vapor in the $\mathrm{NH}$ summer monsoon regions?, J. Geophys. Res.-Atmos., 120, 7988-8001, https://doi.org/10.1002/2015JD023622, 2015.

Rienecker, M. M., Suarez, M. J., Todling, R., Bacmeister, J., Takacs, L., Liu, H.-C., Gu, W., Sienkiewicz, M., Koster, R. D., Gelaro, R., Stajner, I., and Nielsen J. E.: The GEOS-5 data assimilation system - Documentation of versions 5.0.1, 5.1.0, and 5.2.0, Technical Report Series on Global Modeling and Data Assimilation, Volume 27, NASA Goddard Space Flight Center Greenbelt, 2008.

Rosenlof, K. H.: Hemispheric asymmetries in water vapor and inferences about transport in the lower stratosphere, J. Geophys. Res.Atmos., 102, 13213-13234, https://doi.org/10.1029/97JD00873, 1997.
Schoeberl, M., Dessler, A., Ye, H., Wang, T., Avery, M., and Jensen, E.: The impact of gravity waves and cloud nucleation threshold on stratospheric water and tropical tropospheric cloud fraction, Earth Space Sci., 3, 295-305, https://doi.org/10.1002/2016EA000180, 2016.

Schoeberl, M. R. and Dessler, A. E.: Dehydration of the stratosphere, Atmos. Chem. Phys., 11, 8433-8446, https://doi.org/10.5194/acp-11-8433-2011, 2011.

Schoeberl, M. R., Douglass, A. R., Newman, P. A., Lait, L. R., Lary, D., Waters, J., Livesey, N., Froidevaux, L., Lambert, A., Read, W., Filipiak, M. J., and Pumphrey, H. C.: QBO and annual cycle variations in tropical lower stratosphere trace gases from HALOE and Aura MLS observations, J. Geophys. Res.-Atmos., 113, D05301, https://doi.org/10.1029/2007JD008678, 2008.

Schoeberl, M. R., Dessler, A. E., and Wang, T.: Modeling upper tropospheric and lower stratospheric water vapor anomalies, Atmos. Chem. Phys., 13, 7783-7793, https://doi.org/10.5194/acp13-7783-2013, 2013.

Schoeberl, M. R., Dessler, A. E., Wang, T., Avery, M. A., and Jensen, E. J.: Cloud formation, convection, and stratospheric dehydration, Earth Space Sci., 1, 1-17, https://doi.org/10.1002/2014EA000014, 2014.

Schoeberl, M. R., Jensen, E. J., and Woods, S.: Gravity waves amplify upper tropospheric dehydration by clouds, Earth Space Sci., 2, 485-500, https://doi.org/10.1002/2015EA000127, 2015.

Schoeberl, M. R., Jensen, E. J., Pfister, L., Ueyama, R., Avery, M., and Dessler, A. E.: Convective Hydration of the Upper Troposphere and Lower Stratosphere, J. Geophys. Res.-Atmos., 123, 4583-4593, https://doi.org/10.1029/2018JD028286, 2018.

Schoeberl, M. R., Jensen, E. J., Pfister, L., Ueyama, R., Wang, T., Selkirk, H., Avery, M., Thornberry, T., and Dessler, A. E.: Water Vapor, Clouds, and Saturation in the Tropical Tropopause Layer, J. Geophys. Res.-Atmos., 124, 3984-4003, https://doi.org/10.1029/2018JD029849, 2019.

Schwartz, M. J., Read, W. G., Santee, M. L., Livesey, N. J., Froidevaux, L., Lambert, A., and Manney, G. L.: Convectively injected water vapor in the North American summer lowermost stratosphere, Geophys. Res. Lett., 40, 2316-2321, https://doi.org/10.1002/grl.50421, 2013.

Solomon, S., Garcia, R. R., Rowland, F. S., and Wuebbles, D. J.: On the depletion of Antarctic ozone, Nature, 321, 755-758, https://doi.org/10.1038/321755a0, 1986.

Steinwagner, J., Fueglistaler, S., Stiller, G., von Clarmann, T., Kiefer, M., Borsboom, P.-P., van Delden, A., and Röckmann, T.: Tropical dehydration processes constrained by the seasonality of stratospheric deuterated water, Nat. Geosci., 3, 262, https://doi.org/10.1038/ngeo822, 2010.

Ueyama, R., Jensen, E. J., Pfister, L., and Kim, J.-E.: Dynamical, convective, and microphysical control on wintertime distributions of water vapor and clouds in the tropical tropopause layer, J. Geophys. Res.-Atmos., 120, 410-483, https://doi.org/10.1002/2015JD023318, 2015.

Ueyama, R., Jensen, E. J., and Pfister, L.: Convective Influence on the Humidity and Clouds in the Tropical Tropopause Layer During Boreal Summer, J. Geophys. Res.-Atmos., 123, 7576-7593, https://doi.org/10.1029/2018JD028674, 2018.

Vaughan, M. A., Powell, K. A., Winker, D. M., Hostetler, C. A., Kuehn, R. E., Hunt, W. H., Getzewich, B. J., Young, S. A., Liu, Z., and McGill, M. J.: Fully Automated De- 
tection of Cloud and Aerosol Layers in the CALIPSO Lidar Measurements, J. Atmos. Ocean. Tech., 26, 2034-2050, https://doi.org/10.1175/2009JTECHA1228.1, 2009.

Van Vuuren, D. P., Edmonds, J., Kainuma, M., Riahi, K., Thomson, A., Hibbard, K., Hurtt, G. C., Kram, T., Krey, V., Lamarque, J.-F., Masui, T., Meinshausen, M., Nakicenovic, N., Smith, S. J., and Rose, S. K.: The representative concentration pathways: an overview, Clim. Change, 109, 5-31, https://doi.org/10.1007/s10584-011-0148-z, 2011.

Wang, X.: Code and data for acp Wang et al 2019, available at: https://github.com/xunwang15/ Code-and-data-for-acp-Wang-et-al-2019, last access: November 2019.

Wang, X., Dessler, A. E., Schoeberl, M. R., Yu, W., and Wang T.: Water vapor in the tropical tropopause layer to reproduce seasonal cycles in Wang et al paper, last access: 15 September 2019, https://doi.org/10.5281/zenodo.3543818, 2019.

Winker, D.: CALIPSO Lidar Level 2 Cloud Profile Data V4-20, last access: 10 October 2018, https://doi.org/10.5067/CALIOP/CALIPSO/LID_L2_05KMCPROSTANDARD-V4-20, 2018.

Winker, D. M., Vaughan, M. A., Omar, A., Hu, Y., Powell, K. A., Liu, Z., Hunt, W. H., and Young, S. A.: Overview of the CALIPSO Mission and CALIOP Data Processing Algorithms, J. Atmos. Ocean. Tech., 26, 2310-2323, https://doi.org/10.1175/2009jtecha1281.1, 2009.
Winker, D. M., Pelon, J., Coakley, J. A., Ackerman, S. A., Charlson, R. J., Colarco, P. R., Flamant, P., Fu, Q., Hoff, R. M., Kittaka, C., Kubar, T. L., Le Treut, H., Mccormick, M. P., Mégie, G., Poole, L., Powell, K., Trepte, C., Vaughan, M. A., and Wielicki, B. A.: The CALIPSO Mission, B. Am. Meteor. Soc., 91, 1211-1230, https://doi.org/10.1175/2010BAMS3009.1, 2010.

Woods, S., Lawson, R. P., Jensen, E., Bui, T. P., Thornberry, T., Rollins, A., Pfister, L., and Avery, M.: Microphysical Properties of Tropical Tropopause Layer Cirrus, J. Geophys. Res.-Atmos., 123, 6053-6069, https://doi.org/10.1029/2017JD028068, 2018.

World Meteorological Organization: Scientific assessment of ozone depletion: 2010, Global Ozone Research and Monitoring Project-Report No. 52, World Meteorological Organization, Geneva, Switzerland, 2011.

Wright, J. S., Fu, R., Fueglistaler, S., Liu, Y. S., and Zhang, Y.: The influence of summertime convection over Southeast Asia on water vapor in the tropical stratosphere, J. Geophys. Res.-Atmos., 116, 1-12, https://doi.org/10.1029/2010JD015416, 2011.

Ye, H., Dessler, A. E., and Yu, W.: Effects of convective ice evaporation on interannual variability of tropical tropopause layer water vapor, Atmos. Chem. Phys., 18, 4425-4437, https://doi.org/10.5194/acp-18-4425-2018, 2018.

Young, S. A. and Vaughan, M. A.: The Retrieval of Profiles of Particulate Extinction from Cloud-Aerosol Lidar Infrared Pathfinder Satellite Observations (CALIPSO) Data: Algorithm Description, J. Atmos. Ocean. Tech., 26, 1105-1119, https://doi.org/10.1175/2008JTECHA1221.1, 2009. 